\title{
Martsdagene 1848 i Åbenrå
}

Af G. Japsen

${ }^{1}$ I 1848 var den danske bevægelse i Åbenrå en halv snes år gammel. Takket være det arbejde, Frederik Fischer og hans venner havde udf $\phi r t$, fandtes der nu et bevidst dansk parti $i$ byen. Da der under de danske troppers besættelse af Åbenrå $i$ april 1848 var tale om at afskedige det hidtidige bystyre, havde Fischer ingen vanskeligheder med at foreslå fuldt ud egnede kandidater til de 12 poster $i$ deputeretkollegiet². Det danske partis svaghed bestod $i$, at det $i$ overvejende grad fandt sine tilhængere i småborgerskabet, dvs. i kredse, der stærkt f $\emptyset$ lte deres afhængighed af byens $\emptyset$ vrighed og rige borgerskab, og som derfor $i$ stor udstrækning foretrak at holde sig uden for al politik. I Fischers breve vil man finde mange udtryk for hans desperation over dette befolkningslag, der erklærede, at de er ingenting, intet, hverken dansk eller tysk «. Byens underklasse: daglejerne, sфfolkene og tømrerne ved de tre skibsværfter, havde ganske vist lejlighedsvis demonstreret sit danske sindelag, men f $\phi \mathrm{r} 1848 \mathrm{reg}-$ "nede man den hverken fra dansk eller slesvigholstensk side for en politisk faktor.

Set udefra var det danske parti uanseligt og kunne kun pege på få synligế resultațēr. Dets vigtigste aktiver var det af Fischer redigerede *Apenrade Ugeblad", og det ligeledes af Fischer ledede danske bibliotek, begge lige bemærkelsesværdige $i$ en by,

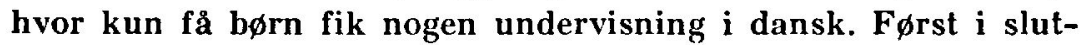
ningen af 1847 f $\varnothing$ lte man sig fra dansk side stærk nok til at kunne iværksætte en aktion $i$ et offentligt anliggende, idet ca. 100 næringsdrivende borgere, under henvisning til en i Fischers blad offentliggjort artikel, vendte sig mod den af den slesvigholstensk-

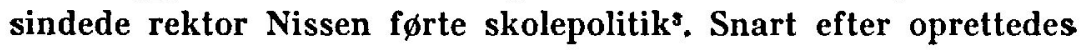


en dansk-orienteret kommunalpolitisk forening, sUnion*, som vakte r $\phi r e, y e d$, at angribe byens sparekasse, fordi den havde anbragt 2000 mark kurant $i$ den slesvigholstenske landsbank4. Men det var også alt. Inden for administration, retsvæsen, skole og kirke var det tyske sprog så enerådende som nogensinde. Ikke èt af sine folkeligt set velbegrundede krav havde danskheden kunnet sætte igennem. Om det så var den meningsløse tyske salmesang ved den danske eftermiddagsgudstjeneste, blev den nu under de tiltagende nationale modsætninger officielt forsvaret som et værdifuldt klenodie.

Den slesvigholstenske retning i Åbenrå var opstået i 1830erne som liberalt parti, vendt mod enevælden og dens embedsmænd, men efter 1840 havde embedsmænd og storborgere fundet hinanden i fælles modsætning til daniseringsbestræbelserne. Omkring 1848, da enevældens afskaffelse kun var et tidsspørgsmål, opfattede disse gammel-slesvigholstenere sig som et i det væsentlige statsbevarende parti; den $\emptyset$ nskede forfatning skulle lovfæste de overleverede statsformer: Hertugdømmernes selvstændighed skulle opretholdes, tysk skulle forblive Hertugdømmernes sțatssprog, og det samlede monarki skulle bevares. Dette program forenede næsten hele Åbenrås overklasse: købmænd, skibsredere og embedsmænd.

Denne traditionsbundne slesvigholstenisme kunne ikke tilfredsstille byens intellektuelle (advokater, læger, lærere etc.) og den del af byens håndværkere, der på grund af afstamning eller uddannelse f $\varnothing$ lte sig knyttet til tyskheden. De foragtede de moderates påberåbelse af gamle traktater og rettigheder og følte sig som en del af den demokratiske stortyske bevægelse. Dette radikale parti gik ind for folkesuverænitet, det $\emptyset$ nskede Hertugd $\varnothing m$ mernes nøjest mulige tilknytning til Tyskland samt Slesvigs optagelse i det Tyske Forbund og dermed monarkiets sprængning. Det tiltagende revolutionære rore i Europa og udsigten til oprettelse af en tysk stormagt gav den radikale tyske retning en mere og mere fremtrædende plads i Åbenrås politiske liv.

Den danske modbevægelse hindrede de moderate slesvigholstenere og navnlig det radikale tyske parti $i$ at skaffe sig den massetilslutning, der var det almindelige i byer, hvor det natio- 


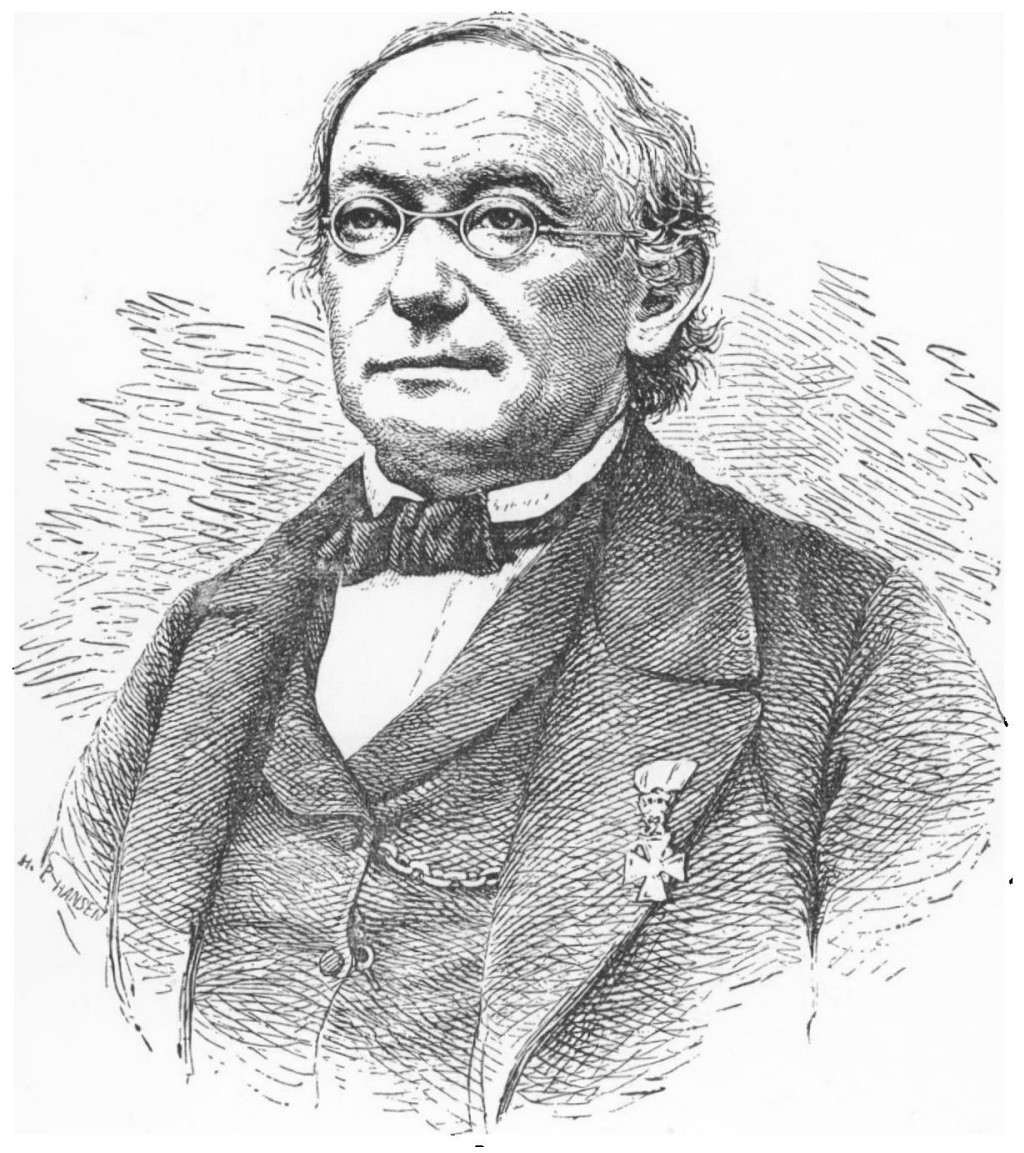

Frederik Fischer

nale problem ikke spillede en lokal rolle (f. eks. i Tønder). De radikale håbede, at en omvæltning i Tyskland og Hertugdømmerne, der gav det demokratiske parti en forende stilling, ville gøre det muligt for dem at drage Åbenrås talstærke småborgerskab over på deres side og dermed reducere danskheden til en ubetydelig sekt.

Den fælles modsætning til den danske bevægelse tvang den slesvigholstenske og den tysk-radikale retning til at holde sam- 
men udadtil. Begge fl $\varnothing j e$ m $\varnothing$ dtes $i$ den af de radikale beherskede »Bürgerverein «, der var oprettet i 1840. Herfra udgik næsten ethvert initiativ $i$ tysk retning. Den moderate fløj deltog kun i ringe grad i det praktiske politiske arbejde. Her dominerede de radikale: mænd som apoteker Hans Karberg og hans broder k $\phi$ bmand Lorenz Karberg (begge fra S $\phi$ nderborg), fysikus v. Maack (født i Hamborg, men opvokset i København), k $\varnothing$ bmand M. H. Lüders (partiets Nestor, født i Tønder), bager Asmus Lorentzen (af Fischer ikke ueffent kaldet "partiets Danton\&) og Hans Kopperholdt, der indtil 1839 havde redigeret byens liberale ugeblad, og som nu igen boede i Åbenrå, vistnok alene optaget af politisk agitation (de to sidstnæunte var indf $\not d t e$ åbenråere).

I Åbenrås selvsupplerende bykollegier fandtes ingen repræsentanter for den dansksindede retning. Deputeretkollegiet havde lige siden 1830erne været domineret af de liberale og ville $i$ en kritisk situation utvivlsomt rette sig efter de radikale. Af dets tolv medlemmer var kun to håndværksmestre, og disse tilh $\emptyset$ rte det tysk-demokratiske parti. Dets to yngste medlemmer: $k \emptyset b-$ mændene Ludolph Davidsen og Jürgen Lorentzen, stod efter Fischers mening den slesvigholstenske bevægelse så fjernt, at deres fjernelse ikke var nødvendig fra et dansk synspunkt ${ }^{5}$. I magistraten henregnedes ældste rådmand, skibsrederen, agent Jørgen Bruhn (byens rigeste mand) til den »loyale«, kongetro retning; bysekretæren, den i Slesvig f $\varnothing$ dte V. A. Suadicani, var moderat slesvigholstener, men søgte som kongelig embedsmand og juridisk sagkyndig at indtage en neutral holdning; af de to andre rådmænd, købmændene J. Ahlmann og M. A. Hartmeyer, støttede den sidstnævnte ivrigt den slesvigholstenske sag.

Endelig var der borgmesteren, Georg Schow, der havde gjort sin entré i Åbenrå som nidkær bekæmper af liberalismen. Han havde dengang kraftigt st $\phi$ ttet Frederik Fischers ans $\phi$ gning om at blive redakt $\varnothing \mathbf{r}$ af byens ugeblad. Den dansk-nationale bevægelses folkelige præg frast $\varnothing \mathrm{dte}$ ham dog langt mere end den liberale slesvigholstenisme, og inden længe samarbejdede han fortrinligt med sine tidligere modstandere i bekæmpelsen af sden danske propaganda«. Han kom derved $i$ et meget tvetydigt forhold til regeringen, hvis antiliberale politik stemte godt overens 


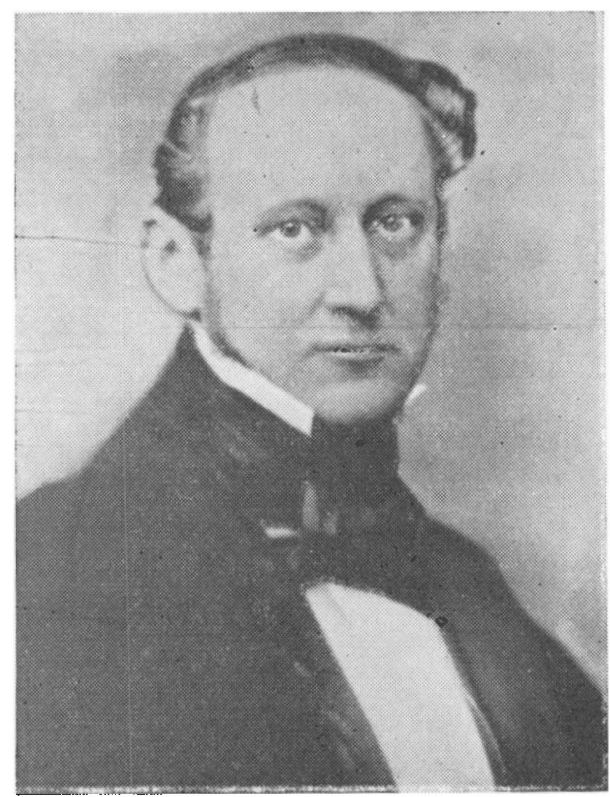

Borgmester

Georg Schow.

med hans arrogante vasen, men hvis kamp mod »de statsopløsende tendenser « han kun støttede på skrømt. I 1847 skrev den nye præsident for den slesvigholstenske regering på Gottorp, L. N. Scheele (en fatter til Georg Schows fader), om ham, at han var en harefod, der snakkede lige eftergivende til begge sider, som altid havde sin fordel for $\emptyset j$ e, og som hørte til dem, der anså den gode sag for tabt og derfor havde vendt sig til den anden'. Der var i $\emptyset$ vrigt ingen tvivl om, at borgmester Schow var en dygtig embedsmand.

\section{OMVELTNINGENS FORBEREDELSE}

$$
\text { 17. 3.-24. } 3 .
$$

Det stærke røre, som forfatningsreskriptet af 28. januar 1848 fremkaldte overalt, sporedes også i ג̇benrå. I februar blev der i Ảbenrå og omegn i stor mængde uddelt eksemplarer af et slesvigholstensk flyveskrift: $\gg$ Das dänische Verfassungs-Reskript 
vom 28. Januar 1848«, som var trykt i Bremen ${ }^{7}$. Den indenlandske spænding $\varnothing$ gedes overordentligt ved efterretningen om monarkiets fald i Frankrig. » Næppe var det blevet bekendt, hvad der er forefaldet i Paris «, skrev Fischer i sit blad, „f $\not r e n d$ man hørte glade forsikringer om, at nu ville »Schleswig-Holstein « snart fremtræde $i$ sin fulde glans\&. Fischer mente dog, at den franske revolution ville give hele Tyskland andet at tage vare på »end at applaudere til den nordalbingiske farce kendt kom det til at gå lige omvendt. Slesvigholstenernes krav blev prøvestenen for den tyske revolutions styrke, og reaktionens sejr i Tyskland ensbetydende med den slesvigholstenske opstands nederlag. Lederne af det radikale parti i Hertugd $\varnothing m-$ merne skønnede nu, at tiden var kommet til at opnå Slesvigs tilknytning til Tyskland ad revolutionær vej.

I de første uger af marts nåede en stigende strøm af foruroligende og ophidsende meddelelser og rygter fra ind- og udland Nordslesvig, men forst den 15. marts blev man her for alvor draget ind $\mathrm{i}$ forberedelserne af den omvæltning, der tilstræbtes af de radikale kredse. Om aftenen på denne dag ankom føreren for den radikale retning i Slesvig, A. W. Beseler, til Haderslev, hvor han mødtes med medlemmer af den slesvigholstenske borgerforening ${ }^{\natural}$. Den rimeligste forklaring på denne rejse få dage f $\varnothing \mathrm{r}$ det afg $\phi$ rende stænderm $\phi d e$ i Rendsborg den 18 marts er, at Beseler har villet sondere de danske nordslesvigeres stilling til det radikale slesvigholstenske partis revolutionsplaner. Det vides, at han forhandlede i timevis med Nis Lorenzen, og Laurids

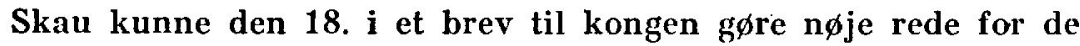
revolutionæres hensigter ${ }^{10}$. Utvivlsomt er det radikale partis tilhængere i Nordslesvig ved denne lejlighed blevet orienteret om den kommende opstand. Om morgenen den 17. (en fredag) forlod Beseler Haderslev for at kunne deltage i det af $\phi \varnothing$ rende $\mathbf{m} \phi$ de i Rendsborg den følgende dag.

På hen- og tilbagerejsen har Beseler sikkert haft samtaler med de radikale ledere $\mathrm{i}$ A benrå. Fischer berettede et par uger senere $^{11}$, at der straks efter Beselers bes $\phi g$ »sporedes $i$ blandt vore schlesvigholsteinere mere bevægelse og en mere truende kækhed end nogensinde. Man hørte ytringer, inden søndagen 
ville alting være afgjort og det danske åg afkastet«. Beselers meningsfæller i Åbenrå indledte deres del af den fælles aktion samme dag, som Beseler forlod Haderslev. Det af de radikale beherskede deputeretkollegium foreslog nemlig den 17., at der skulle oprettes en borgervæbning til opretholdelse af ordenen $i$ påkommende tilfælde«. I et møde, hvori begge bykollegier deltog, satte magistraten dog igennem, at man forst skulle indhente Gottorp-regeringens tilladelse, og $i$ ans $\varnothing$ gningen taltes der afdæmpet om $\gg$ oprettelse af en sikkerhedsvagt til st $\phi$ tte for politiet «. Den 18. marts afsendtes andragendet til Slesvig.

Den revolutionære bevægelses fremtrængen ledsagedes overalt af oprettelse af borgervæbninger. Ingen var i tvivl om, at de radikale $\varnothing$ nskede at bruge disse bevæbnede korps til at give deres krav eftertryk over for magthaverne, selvom man udadtil gav det udseende af, at man væbnede sig mod »communistiske 'T'endentser ${ }^{15}$. I den givne situation bet $\varnothing d$ oprettelsen af den åbenråske borgervæbning, at hovedindflydelsen $i$ byen var ved at gå over til det tyske omvæltningsparti. Myndighederne vovede ikke at modsætte sig korpsets oprettelse, thi i den »mere opildnede og intelligente del af borgerskabet $\ll$, skrev borgmester Schow den 15. april i sit forsvarsskrift ${ }^{13}$, var stemningen sådan, at disse i givet fald ville have oprettet borgervæbningen mod фvrighedens vilje. For at forhindre, at det radikale element på denne måde fik magten i borgervæbningen, fortæller Schow, så han ikke anden udvej end at gå med til oprettelse af en sikkerhedsvagt, ved hvis hjælp de forskellige partier i Ảbenrå i fællesskab skulle opretholde ro, orden og sikkerhed.

S $\varnothing$ ndag d. 19. marts om aftenen nåede meddelelsen om Rendsborg-m $\varnothing$ dets beslutninger til Åbenrå. Da borgmester Schow hørte, at der var nedsat et tremandsudvalg bestående af Beseler, Reventlow og Bargum, og at en deputation skulle bringe Hertugdømmernes ultimatum (som han selv kalder det) til København, stod det ham klart, at der nu forestod set alvorligt brud mellem Hertugdømmerne og Kongeriget «. Han besluttede derfor straks at rejse til Slesvig for at rådføre sig med ledende embedsmænd i den slesvigholstenske regering. Den 20 . marts om aftenen ankom Schow til Slesvig, hvor han først talte med borgmester 
Jensen, derpå med regeringspræsident von Scheele og med regeringsråderne v. Harbou og Heinzelmann. Af de to sidstnarnte fik han et råd, der passede ham, fordi det svarede til den holdning, han selv havde indtaget $i$ borgervebningssagen: At gøre modstand ville kun betyde at gyde olie på ilden; det var derfor myndighedernes pligt at søge at bevare ledelsen af bevægelsen for dog at kunne afværge excesser mod personer og ejendom. Han erfarede tillige, at Gottorp-regeringen var kommet Åbenrảs andragende om tilladelse til at oprette en sikkerhedsvagt $i$ for$k \varnothing b e t$ og $i$ et cirkulære til alle magistrater havde opfordret disse til at oprette sådanne vagter. Endelig h $\varnothing$ rte han, at Scheele havde sendt regeringsråd Höpfner til København og gennem ham anmodet om sin afsked.

Tidlig tirsdag morgen (den 21. marts) forlod Schow Slesvig, bestyrket $i$ sin opfattelse af ikke at burde yde modstand mod den slesvigholstenske omvæltning. I Flensborg aflagde han på hjemrejsen fra Slesvig visit hos borgmester Chr. Fr. Callisen vel sagtens for at påvirke ham til at indtage en lignende holdning over for opstanden. I Åbenrå indkaldte han endnu samme dag bykollegierne til møde og satte dem ind i situationen. Det gjaldt nu om hurtigst muligt at få oprettet borgervæbningen. Man vedtog et foreløbigt reglement for korpset, godkendte en offentlig kundgørelse om oprettelsen og opfordrede alle interesserede til at samles på rådhuset den 23 . marts kl. 9, hvor indregistreringen skulle foretages af bykollegierne. Endvidere sendte man to kommissæerer til Hamborg for at købe 200 geværer med bajonet, da der ikke fandtes passende våben i Åbenråă ${ }^{14}$. På denne travle dag skrev Schow også et brev til en bekendt, kancellideputeret Adolf v. Moltke i København (en broder til postmesteren i Åbenrå). Han фnskede åbenbart at fremstå som den for landets vel bekymrede kongetjener. Han skildrede den faretruende stemning og bad Moltke viderebringe hans ord til kongen. Stormen kunne forebygges ved rettidige indrømmelser, skrev han, idet han tilf $\varnothing j e d e$, at en $\phi j e b l i k k e l i g$ afgørelse af spørgsmålet om Slesvigs optagelse i det Tyske Forbund ikke var påkrævet, da der herskede delte meninger herom i Hertugd $\varnothing$ mmerne ${ }^{15}$.

Den følgende dag offentliggjordes opråbet om sikkerhedskorp- 
sets oprettelse i Apenrade Ugehlad. Fischer havde åbenbart tænkt sig at tage kraftigt til orde mod den slesvigholstenske opstand, men Schow bevægede ham til »frivilligt at trakke to ophidsende artikler tilbage «, idet han $i$ en samtale stillede ham $i$ udsigt, at både hans trykkerpresse og hans hus i modsat fald ville blive ødelagt, »wobei aller Wahrscheinlichkeit nach auch seine Person nicht leer ausgegangen wäre $\ll^{16}$. Fischer skriver mindre sn $\emptyset$ rklet, at Schow erklærede, »at han ikke i mindste måde indestod for hans (redakt.s) og hans families liv ${ }^{17}$. Episoden viser, hvor spændt stemningen i byen var, og hvor afmæitigt det danske parti følte sig, også forud for den provisoriske regerings dannelse.

Torsdag den 23. marts indledtes den slesvigholstenske opstand. Berlingske Tidendes meddelelse om martsministeriets dannelse nåede på denne dag Hertugdømmerne og satte lavinen $i$ skred. Meddelelsen blev også læst i Åbenrå og dens betydning forstået. Den radikale lederkreds besluttede $\varnothing$ jeblikkeligt at sende en pålidelig mand til Beseler i Slesvig for at tilskynde til hurtig handling. Valget faldt på Hans Kopperholdt, og denne rejste sporenstregs til Slesvig. Ved ankomsten hertil viste det sig imidlertid, at Beseler allerede var blevet underrettet og en time forinden var taget til Kiel ${ }^{18}$. - I Åbenrå indtegnedes på denne dag ca. 125 medlemmer af sikkerhedskorpset, fortæller Schow, og tallet steg i løbet af de følgende dage til ca. det dobbelte.

Natten mellem den 23. og 24. marts proklameredes den provisoriske regering i Kiel, og om formiddagen den 24. satte den sig i besiddelse af Rendsborg fæstning. Meddelelsen om den provisoriske regerings dannelse blev bragt til Ảbenrå af Kopperholdt. Han h $\phi$ rte den store nyhed om morgenen den 24. marts hos den kendte slesvigholstenske politiker C.F. Heiberg i Slesvig. »Jeg ilede tilbage $\ll$, fortalte han i 1850, »bragte den f $\not$ rste besked til Flensborg og bekræftede over for Bremer, at han skulle være medlem af den provisoriske regering. Uden for byen stod jeg af vognen, gik til fods gennem byen og fik flensborgerne på benene. Min meddelelse om, at preusserne kunne være der om få dage, satte $\bmod i$ vort derværende parti $\ll$. Det $t \varnothing r$ herefter antages, at 
meddelelsen om den provisoriske regerings dannelse náede til Ábenrå ud på eftermiddagen. Det radikale partis ledere mødtes straks til en hemmelig rådslagning hos $\mathrm{k} \phi b$ bmand Lorenz Karberg. For at opnå Abenrå bys officielle anerkendelse af den nye regering satte de sig dernæst $i$ forbindelse med borgmester Schow. Under denne samtale viste det sig, at Schow uforbeholdent stillede sig på revolutionens side. Kopperholdt fortæller udtrykkeligt, at Schow $\gg$ i overvarelse af Deres broder [dvs. Lorenz Karberg] over for mig erklærede sin venlige anerkendelse af den provisoriske regering, og dette skete før De [dvs. apoteker Hans Karberg] ankom fra Rendsborg med den trykte proklamation, altså før vi vidste, at den provisoriske regering havde dannet sig i Frederik d. 7.s navn «.

Den mand, der i sin tid, som enevældens repræsentant, havde udsat Kopperholdt for årelange chikaner, rakte ham nu hånden til støtte for en revolutionær regering! Schow selv nævner forståeligt nok ikke samarbejdet med revolutionspartiet. Hans fremstilling af begivenhederne $i$ en lang erklæring dat. 15. april er vidnesbyrd om et omhyggeligt tilrettelagt forsvar, der har til formål at vælte oprørsanklagen fra hans skuldre. Sådan skrev han på et tidspunkt, da de kongelige tropper havde besat hele Slesvig, og de fleste embedsmænd havde afgivet forsikring om deres troskab mod kongen. I maj og juni, da Schow stod foran sine dommere, var den militære og politiske situation imidlertid ganske forandret: den provisoriske regering herskede $\mathrm{i}$ begge hertugd $\varnothing \mathrm{m}-$ mer, tyske tropper stod i Jylland, og en tysk stormagt var ved at opstå. Hvad der før havde varet en forbrydelse, blev nu Schows hæder; mens han tidligere havde skildret sig selv som en mand, der af en ophidset folkehob var blevet tvunget til at gøre gode miner til slet spil, hedder det nu i retsprotokollen: $\gg$ Da dette brud [mellem Kongeriget og Hertugd $\phi$ mmerne] virkelig indtraf, havde komparenten fuldstændig tilsluttet sig bevægelsen«, ja, Schow erkender, at han whar stillet sig i spidsen for bevægelsen ${ }^{10}$. Schows holdning både under og efter disse skelsættende dage bekræftede ganske Scheeles karakteristik af ham: han var altid at finde på de stærkestes side. 


\section{OMVALTNINGENS GENNEMF $\emptyset$ RELSE}

\section{3.-25. 3 .}

På grundlag af Schows egen beskrivelse af sine bevægelser den 24. marts, af de forsigtige udtalelser, der blev fremsat af medlemmer af bykollegierne og af kommunale bestillingsmænd under et forhør i Åbenrå den 13. april, og af Kopperholdts ovenfor citerede brev, kan man tegne f $\varnothing$ lgende billede af dagens begivenheder i Ábenrå:

Schow havde, lige siden han i Berlingske Tidende læste om. martsministeriets udnævnelse, været klar over, at det brud, han havde ventet lige siden Rendsborg-mødet, nu var ved at ske. Fra en svoger, der var ansat som volont $\emptyset r$ i det slesvigholstenske kancelli, modtog han et brev, hvori det hed, at kongen havde måttet opgive al magt. Henimod aften fik Schow en øjenvidneskildring fra København. Den blev givet af kancellisekretær v. Warnstedt, der, ligesom flere andre, passerede Åbenrå efter i protest mod udviklingen i Kongeriget at have forladt sit embede i København. Lidt senere sendte amtmand v. Stemann bud efter Schow. Det viste sig, at Stemann havde bes $\varnothing \mathrm{g}$ af regeringsråd Höpfner og grev Arthur Reventlow, der var på gennemrejse fra Slesvig. De fortalte om oprettelsen af den provisoriske regering, om besættelsen af Rendsborg fæstning og om den slesvigholstenske regerings opløsning. De rejste straks videre, mens Schow blev tilbage for sammen med Stemann at drofte, hvilken holdning de skulle tage til begivenhederne. De enedes om, siger Schow, »at lade sig lede af omstændighederne«. På vejen hjem fortalte Schow nyhederne til bysekretær Suadicani, som han traf hos sin moder (de boede i samme hus i Slotsgade). I sin skriftlige erklæring siger Schow, at han havde håbet, at de strøstesløse efterretninger kunne hemmeligholdes til den følgende dag. Da han på sin videre vej kom over torvet, traf han imidlertid »en mængde h $\emptyset$ jst ophidsede mennesker «, der forlangte, at han straks skulle anerkende den provisoriske regering. Han svarede dem, siger han, at dette spørgsmål måtte af gøres af bykollegierne, hvis beslutning han ville bøje sig for. Man kan ga ud fra, at både de revolutionære slesvigholstenere og Schow er gået til tor- 


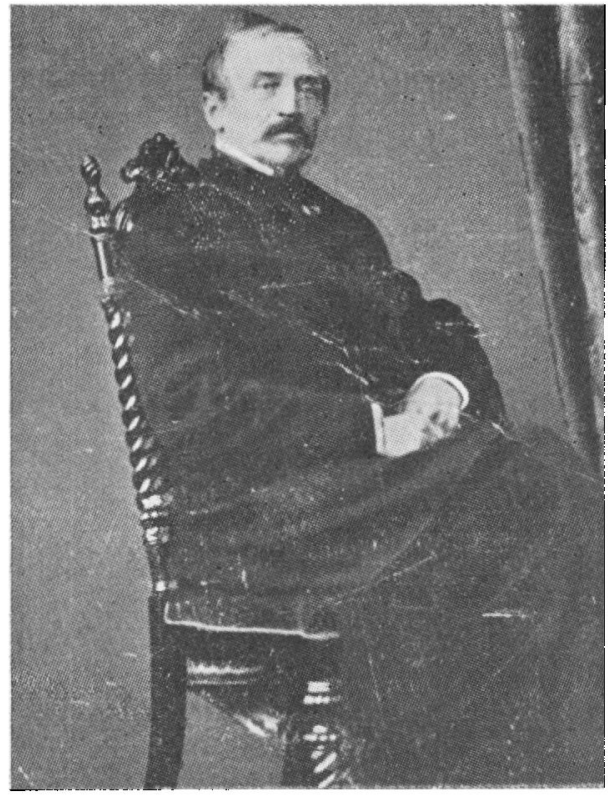

vet på dette sene tidspunkt for at høre, hvilke nyheđer der måtte komme med posten syd fra ved 11 -tiden.

Med diligencen ankom denne aften apoteker Karberg, som fra Rendsborg modbragte den provisoriske regerings kendte proklamation, hvori magtovertagelsen begrundedes med, at kongen var ufri. Først med denne proklamation var der skabt mulighed for at gennemf $\phi r e$ byens officielle anerkendelse af den nye regerings. Gennem samtalen med Kopperholdt og købmand Karberg var Schow orienteret på forhånd. Han kunne derfor straks tage ledelsen og handle med sadvanlig hurtighed og myndighed*.

* Samtalen mellem Schow, Kopperholdt og Karberg har nıuligvis fundet sted hos bysekretar Suadicani efter Schows bes $\emptyset \mathrm{g}$ på Brundlund. Det er i hvert fald påfaldende, at Schows bes $\phi g$ hos Suadicani oprindelig hverken blev navnt af Schow i dennes detaillerede redeg $\phi$ relse for sine bevægelser om aftenen den 24. marts eller af Suadicani under forhøret den 13. april. Det kom kun frem, fordi Suadicani sikkert urigtigt - under dette forh $\emptyset \mathrm{r}$ påstod, at det var Schow selv, der henved midnat havde hentet ham til byrådsmøde. Under forh $\emptyset-$ rene afviste Schow kategorisk denne påstand og nævnede så, at han havde truffet Suadicani hos sin moder. 
Ved 11-tiden gik Schow over til rådsbetjent Ipland, der havde bolig på selve rådhuset, og bad ham indkalde bykollegierne til møde klokken tolv nat. Ipland havde næppe faet tændt lys, fortalte han under forh $\emptyset r e t$ den 13. april, f $\emptyset r$ rådhuset fyldtes af det radikale partis tilhæengere, deriblandt en del fremmede. I mødesalens ene hjørne anbragtes apoteker Karbergs sort-rødgyldne tyske revolutionsfane som et symbol på, at man opfattede omvaltningen som en del af den tyske friheds- og enhedsbevagelse. I et andet hjørne stod en fane, der tør identificeres med en rød slesvigholstensk fane med løver og nældeblade $i$ et felt $i$ midten. »Die unvergessliche Geisterstunde« kalder Kopperholdt det natlige $m \varnothing d e$, da Åbenrå by, først af alle nordslesvigske stæder og tidligere end Flensbors, anerkendte den provisoriske regering, flere dage f $\phi r$ den skriftlige opfordring hertil forelå. Det var omvaltningspartiets triumf. "Folkemængden var bevæget, og det gik meget stormfuldt til, dog uden voldsomhed «, således skildrede agent Bruhn den 13. april atmosfæren under mødet. "Omgivet af en talrig menneskemangde oplaste Schow den provisoriske regerings proklamation. For at sikre en enstemmig godkendelse betonede Schow kraftigt den nye regerings lovlydighed. Rådmand Ahlmann, der sad i nærheden af borgmesteren under det natlige møde, forklarede under forh $\emptyset$ ret, at Schow efter oplæsningen spurgte, om de ville tiltræede den provisoriske regering, der jo handlede $i$ kongens navn og ville af give styrelsen, så snart kongen atter var fri. Schow konciperede nu på stedet en skrivelse til den provisoriske regering, som han læste op for de tilstedeværende, og som alle medlemmer af bykollegierne derpå underskrev. En drøftelse fandt ikke sted, og ingen uden Schow synes at have taget ordet. Det underskrevne aktstykke var meget forsigtigt affattet. If $\varnothing$ lge Suadicani erklærede man, at kommunens repræsentanter holdt det for deres pligt $\mathbf{i}$ overensstemmelse med kommunens $\varnothing n s k e r$ at underkaste sig regeringens befalinger. I sin erklæring af 8 . april til regeringskommissionen undskyldte magistraten sin holdning med, at det var dens pligt »ikke at give slip på ordenens tøjler«. Der er ingen grund til at tro, at magistraten hermed afgav et falsk vidnesbyrd. De moderate slesvigholstenere var endnu langt fra overbevist om, 
at en statsomvæltning var en nødvendighed; for dem var de radikales dominerende rolle et onde, man måtte affinde sig med, så længe det revolutionære r $\emptyset$ re varede ved ${ }^{20}$.

Allerede da klokken var to om natten, kunne Lorenz Karberg og fysikus v. Maack sætte sig i postvognen for at bringe anerkendelsen til Rendsborg ${ }^{91}$. De forsamlede slesvigholstenere drog fra rådhuset med faner $i$ spidsen og syngende $\gg$ Schleswig-Holstein meerumschlungen \& gennem byens gader ${ }^{22}$.

I nattens $l \varnothing b$ blev den slesvigholstenske regerings proklamation trykt og ved daggry på magistratens foranstaltning opklæbet på gadehjørnerne, og embedsmændene $\mathrm{i}$ byen fik $\mathrm{i}$ konvolut med magistratens segl tilstillet to eksemplarer af den ${ }^{23}$.

Nu trådte også sikkerhedskorpset i funktion som det nye styres væbnede magt. Dets ledende mænd, der delvis var identiske med det radikale partis f $\varnothing$ rere, var $n \varnothing j e$ forbundet med bykollegiernes medlemmer. Borgmester Schow havde derfor ingen vanskelighed med at bevare kontrollen over det og afholde' det fra ubesindigheder som en planlagt demonstration mod amtmanden for at få ham til at erklære sig for den provisoriske regering eller et eventyrligt togt til Haderslev for at tvinge myndighederne der til det samme ${ }^{24}$. Korpsets chef var ejeren af kancelligodset Høgebjerg, kaptajn og skibsreder Hans Bruhn, en broder til agenten, men modsat denne en ivrig tilhænger af den protyske retninges. Blandt korpsets $\varnothing$ vrige ledende personer nævnes advokat H. J. Nissen ${ }^{28}$ og navnlig apoteker Hans Karberg. Han var sen af dem, der gjorde sig overordentlig umage for efter fattig evne at spille en vild jakobiners rolle*, hedder det 4. 4. 1848 i Apenrade Ugeblad; »beladt med en del våben rendte han omkring med de mest bydende ord og fagter og gjorde allevegne sin myndighed gældende«. Korpsets medlemmer var kendelige på et hvidt bind om armen og kokarde $i$ huen. Indtil de $i$ Hamborg bestilte geværer ankom, bestod deres bevæbning af sjagtgeværer, pistoler og en enkelt sabel « ${ }^{27}$.

De revolutionære slesvigholstenere opfattede som nævnt omræltningen som en del af den tyske enhedsbevægelse, og det var dennes sort-rød-gyldne farver, der prægede martsdagene. Fra rådhusets vinduer vajede fra om morgenen den 15 . de to flag, 
der om natten havde været anbragt $\mathrm{i}$ mødesalen. På torvet (vel sagtens hos apoteker Karberg) vajede et sort-r $\varnothing d$-gyldent flag ${ }^{-8}$, og både Schow og Fischer fortæller, at de fleste af de sløjfer og kokarder, der blev båret, ligeledes var i disse farver. Andre iagttagere (agent Bruhn, vægter H. C. Nielsen, Gamborg, Suadicani) taler skiftevis om tyske, slesvigholstenske og oprørsflag, uden at det er klart, hvilken fane der sigtes til. Den samme tvivl g $\phi \mathbf{r}$ sig gældende med hensyn til sikkerhedskorpsets kokarder, der efter alt at dømme også har været sort-rød-gyldne, selv om Gamborg kalder dem slesvigholstenske.

Sikkerhedskorpset trådte $i$ aktion efter en velovervejet plan. Det blev straks om morgenen sat ind på to fronter: mod det danske partis ledende mænd $i$ byen, og mod de farer man frygtede fra den danske landbefolknings side. For at imødega den sidstnæunte trussel blev alle indgange til byen besat og alle indog udpasserende anholdt. På Schows ordre opstilledes der vagtposter hos de danske førere Fischer og Grauer. Flere danske borgere blev tvunget til at underskrive en revers og give håndslag på, at de ville afholde sig fra alle danske »Umtriebe «. Fischer fik besked om, at hans blad kun måtte udkomme, hvis det blev redigeret $i$ slesvig-holstensk and ${ }^{29}$. Op ad dagen fandt $\mathrm{Fi}$ scher det rådeligst at forlade byen og fik af Schow frit lejde til at tage til Kolding. Da professor Paulsen fra Kiel om eftermiddagen passerede Åbenrå på vej nordpå og tog ind hos Fischer, var denne rejst ${ }^{30}$. Både Paulsen og baron Eggers fra Slesvig blev under deres ophold i Åbenrå forsynet med »beskyttelsesvagter « ${ }^{31}$. Gamborg giver $i$ sine dagbogsoptegnelser et for dagen typisk stemningsbillede: »Klokken 11 om aftenen kom diligencen, og jeg gik op på postgården for at se prof. Paulsen afrejse med samme. Straks derpå så jeg ham komme i midten af en afdeling af den frivillige borgervagt, som anf $\phi$ rtes af min principal ${ }^{32}$, med dragen sabel. Også borgmester Schow og flere bekendte slesvigholstenere, hvoriblandt apoteker Karberg, havde indfundet sig og omringede professor Paulsen og diligencen under idelige forhånelser «. Således blev byens dansksindede parti gjort tars.

Alle disse revolutionshandlinger udgik fra det tysk-radikale parti, der i martsdagene helt havde byen i sin magt. Det virkede 
med energi, ja fanatisme for den stortyske tankes sejr i Åbenrå. Disse bestræbelser mødte fjendskab fra dansk side, skepsis hos gammel-slesvigholstenerne og slet ingen forståelse hos almuen. Andet var heller ikke at vente $i$ en by som Åbenrå, hvis indbyggere kun havde en meget svag forbindelse med Tyskland. Omvæltningspartiets stilling kunne være blevet langt stærkere, hvis det havde søgt at realisere sine demokratiske programpunkter. Der kendes imidlertid ingen handling og ingen udtalelse fra dets side, som røber interesse for de brede lag. Det havde derved på forhånd sat sig selv ud af spillet som leder af almuen, der netop nu rejste sig af sin politiske søvn, vakt til dåd af det poiitiske uvejr.

For at formå embedsmændene $\mathrm{i}$ byen til at adlyde den provisoriske regering, aflagde borgmester Schow sammen med den $\phi \mathrm{v}-$ rige magistrat (sikkert med undtagelse af agent Bruhn) bes $\phi \mathrm{g}$ hos dem i dagens $l \varnothing b$. Pressionen gav det $\varnothing$ nskede resultat, idet dog den lige udnævnte amtsforvalter Krogh gav et undvigende svar, og postmester Moltke erklærede, at han ikke ville vige et skridt fra den ed, han havde aflagt til kongen ${ }^{33}$. Det fremgår $i$ $\emptyset$ vrigt klart af det fremf $\varnothing$ rte, at embedsmandene i Åbenrå hverken var opstandens bagmend eller tog ledende del $i$ den.

Borgmester Schow fik i løbet af den 25. endnu engang lejlighed til at vise, hvor fuldstændigt han havde tilsluttet sig revolutionen. Oberst v. Holstein, der var på vej nordpå med den del af dragonerne fra Slesvig, som var forblevet tro mod den danske regering, forlangte hos amtmand von Stemann fri ret til gennemmarch gennem Åbenrå (de var formentlig blevet standset af sikkerhedskorpsets vagtposter). Stemann tilkaldte Schow og Suadicani. Henvendt til v. Holstein erklærede Schow imidlertid, efter hvad han oplyste under forh $\varnothing$ ret den 31 . 5., at gennemmarchen ville volde vanskeligheder, og at militæret $i$ hvert fald måtte aflevere våbnene. Da v. Holstein kategorisk af viste dette krav, erklærede Schow, at han ville forelægge spørgsmålet for bykollegierne. Oberst v. Holstein har tilsyneladende også bragt spørgsmålet om kvarter for de troblevne jægere fra Slesvig på bane, og under forh $\emptyset$ ret blev Schow beskyldt for at have nægtet disse kvarter. Schow svarede, at dette spørgsmål vistnok slet ikke 
havde været berørt, men det kan ikke være rigtigt, thi ifølge borgerprotokollen besluttede bykollegierne at give jagerne kvarter $\mathrm{i}$ byen, hvis det skulle blive forlangt. Her er åbenbart igen tale om et tilfælde, hvor Schows holdning var mere stejl end det $\emptyset$ vrige bystyres. Borgerprotokollen nævner i фvrigt ikke dragonerne; sandsynligvis fordi de på det tidspunkt, bykollegierne holdt deres møde, havde fortsat deres march nordpå uden om byen. Heller ikke jægerne marcherede gennem Åbenrå.

Bykollegierne samledes denne dag for efter den fuldbyrdedeomvæltning at godkende en indberetning om situationen til den provisoriske regering. Agent Bruhn deltog betegnende nok ikke i dette møde. Selve indberetningen er ikke bevaret, men af udtalelser af Schow og af dr. Marcus (den f $\varnothing$ rende slesvigholstenske politiker i Haderslev) under forh $\varnothing$ rene $^{34}$ fremgår, at indberetningen blev affattet, efter at embedsmandene var blevet adspurgt, om de ville anerkende den provisoriske regering, og at meddelelsen herom udgjorde indberetningens vigtigste punkt. Marcus oplyste desuden, at der $\mathrm{i}$ indberetningen havde ståt, at der vajede tyske faner fra rådhuset, at Fischer og Grauer var 》arresteret «, og at byen $\emptyset$ nskede væbnet hjælp mod den ophidsede landbefolkning.

Det er tænkeligt, at man ved indberetningens formulering har haft den agitatoriske virkning for $\varnothing j e$, som den kunne $\emptyset v e$ på udviklingen i Haderslev, hvor den provisoriske regering stadig ikke var blevet anerkendt. I hvert fald blev der taget en afskrift af såvel denne indberetning som af det på det natlige møde underskrevne dokument, og de blev sammen med eksemplarer af den provisoriske regerings proklamation bragt til Haderslev af advokat Nissen; også Schows husvært, købmand Marcus, en broder til dr. Marcus, rejste til Haderslev. Her havde den slesvigholstenske borgerforening dagen igennem udfoldet de st $\phi$ rste bestræbelser for at få magistraten til at anerkende den provisoriske regering. Sent om aftenen oplæstes skrivelserne fra Åbenrå i borgerforeningen i Haderslev, og med dem i hånden gik dr. Marcus henimod klokken fire om morgenen den 26. 3. til borgmester Lassen og forlangte, at Haderslev skulle følge Åbenrås eksempel. I sidste $\emptyset$ jeblik fik Lassen sagens afgørelse udskudt 
til samme dags formiddag, og på dette tidspunkt lykkedes det ham som bekendt ved direkte appel til borgerne at forhindre anerkendelsen af den provisoriske regering.

Også i Tønder virkede Åbenrås resolutte overgang til den provisoriske regerings side som et ildnende eksempel. To af de sfremmede», som overværede den natlige anerkendelse af den provisoriske regering i Ȧbenrå, var kendte T $\not$ nder-borgere: k $\emptyset \mathbf{b}-$ mand I. C. Todsen og kæmner Rehhoff (en broder til provsten $i$ Åbenrå). Den førstnævnte var den 24. 3. blevet sendt til Åbenrå for at $k \phi b e$ geværer til en t $\varnothing$ ndersk borgergarde, som bykollegierne dagen $i$ forvejen havde vedtaget at oprette ${ }^{35}$. Ved middagstid den 25. 3. kom de tilbage til Tønder, hvor bykollegierne netop var forsamlet til møde. $\gg$ Vi begav os straks til disse for at aflægge beretning om det, vi havde set og erfaret i Åbenrå «, skrev Todsen 28. 3. til Karberg i Abenråa. Magistraten og de -deputerede var imidlertid så forsigtige, at de ville afvente en direkte henvendelse fra den provisoriske regering. F $\phi$ rst da denne var kommet den 26. 3., gik bykollegierne ind på det almindelige krav. Man kunne derfor en uge senere over for kongen fremhæve, at Tønder var »die letzte der sich fügenden Städte «\$7. Også i Flensborg bøjede bykollegierne sig 26. 3. for den provisoriske regerings netop indl $\phi$ bne krav om anerkendelse ${ }^{38}$, medens Sønderborg, hvortil meddelelsen om den provisoriske regerings dannelse først nåede den 27. 3., besluttede at se tiden an; byen havde endnu ikke truffet et endeligt valg, da danske krigsskibes .ankomst den 28 . 3. af gjorde sagen ${ }^{30}$.

\section{OMVALTNINGSPARTIET VED MAGTEN}

$$
\text { 26. 3.-28. } 3 .
$$

S $\varnothing$ ndag den 26. marts oprandt som en stille og rolig dag. Man så ikke engang »de oprørske faner $\aleph^{40}$. På denne dag indløb imidlertid fra den provisoriske regering en ordre (dat. 25. 3.) om straks at dirigere de til Fredericia indkaldte reserver til Rendsborg $^{41}$. Sikkerhedskorpset påtog sig med iver at udføre denne ordre, og medlemmernes kampmod er sikkert blevet $\phi$ get ved, at de i Hamborg indk $\varnothing$ bte geværer ankom henimod aften ${ }^{42}$. Fra 
og med denne dag anholdtes alle landreserver, der søgte at passere Åbenrå på vej til Fredericia, af sikkerhedskorpsets vagter ${ }^{4: 3}$. De blev ført til rådhuset, hvor de fremstilledes for Schow eller rådmændene, »som $i$ hiine Bevagelsens Dage vare for den største Deel tilstede paa Raadstuen ${ }^{44}$. If $\phi l g e$ Schow havde den provisoriske regering pålagt myndighederne ikke at tvinge de indkaldte til at tage til Rendsborg, men opfordre dem til at begive sig til deres hjem. I Åbenrå gik man imidlertid under Schows ledelse langt videre. Nogle blev beordret til Rendsborg, mens andre, der nxgtede, fik frataget deres pas. 27. og 28. 3. sendte Schow lister over afviste reserver til amtshusene i S $\phi$ nderborg og Nordborg, ledsaget af opfordringer til at kontramandere de tidligere udstedte indkaldelsesordrer. Disse åbenlyst oprørske handlinger kom til at danne hovedanklagen mod borgmester Schow og blev den umiddelbare årsag til hans arrestation. I sit forsvarsskrift søgte han forstảeligt nok at svakke betydningen af disse skridt: han havde ikke udøvet tvang mod reserverne, og det havde stảet dem frit for at gå syd på ud af byen og så >auf einem ganz kleinen Umwege $\bmod$ nord. Hvis man så uhildet på situationen, tilføjede han, måtte man indrømme, at den valgte fremgangsmåde ikke havde skadet indkaldelsen: „Overordentlige tidsomstæendigheder kræver imidlertid usædvanlige forholdsregler . Over for anklagens store bevismateriale indrømmede Schow dog 23. 5, at beskyldningerne var rigtige, men fremstillede det skete som >en følge af tvingende forhold «; initiativet var udgåt fra folket, og han havde måttet fortsætte ad den vej, han var slået ind på. I det sidste forhør, den 28. 6., sagde han endelig rent ud, at »når man havde anerkendt den provisoriske regering, var det en simpel konsekvens at omdirigere reserverne«.

Efterhånden som de tilbageviste reserver nåede frem til deres garnison og der berettede om, hvad de havde varet udsat for $i$ Åbenrå, dannede der sig i hærens ledelse et billede af en by, hvis borgere var fanatiske oprorere mod deres konge. I en rapport fra 3. infanteribrigade i Fredericia 28. $3 .^{4 \overline{3}}$ hedder det f. eks.: »I Apenrade blev de standsede, man tog bidslet af hestene for at standse vognene, men de kom dog igennem«. 29. 3. rapporterede hovedkvarteret for det nørrejydske korps i Haderslevi6: ${ }^{4}$ Apen- 
rade anholder man bestandig de reserver, der frivilligt strømmer ind til os; man sætter dem i fængsel, indtil de lover at gå til Rendsborg i stedet for til Kolding; i dette $\phi$ jeblik melder sig en reserve, som man har r $\varnothing$ vet sko og strømper fra; hans kammerater har mistet trøjer, veste osv. Disse excesser for $\phi$ ves af Apenrade borgere . Samme dag rapporterede postmesteren i Fredericia til generalpostdirektionen: $\gg$ De indkomne frifolk har formelig måttet slå sig igennem Apenrade; passene er frataget dem; marchpenge har de ikke erholdt, og embedsmændene har villet forcere dem til at gå til Rendsborg $\ll^{47}$. Fra selve Åbenrå foreligger også et par udtalelser om tilbageholdelserne: Vægter H. C. Nielsen oplyste 13. 4., at murmester Frederik Schultz »har i en afstand af omtrent $1 / 2$ mil herfra byen indhentet og her til stedet tilbagef $\not r t$ noget på vejen til Fredericia værende mandskab «, og rådsbetjent Ipland nævnede, at især apoteker Karberg havde været virksom ved tilbageholdelsen af de indkaldte ${ }^{48}$.

Harmen på dansk side vendte sig imidlertid ikke blot mod Åbenrå by og dens borgmester, men også mod amtmand v. Stemann, der den 26. 3. lod sig bevæge til at adlyde den provisoriske regerings ordre om at indkalde mandskabet til Rendsborg i stedet for til Fredericia ${ }^{40}$. Man troede, at dette skridt $\gg$ har haft til følge, at en stor del af amtets værnepligtige mandskab, som ellers ville være bleven indkaldt til Hans Majestæt Kongens tjeneste, befinder sig i de fjendtlige rækker $\aleph^{50}$. Det viste sig imidlertid hurtigt, at amtmanden »ikke med nogen særdeles iver havde efterkommet denne ordre, og at adskillige af de indkaldte slet ikke var taget afsted ${ }^{51}$. Anholdelsen af reserverne i Åbenrå havde Stemann ingen andel $\mathbf{i}$ og billigede den ikke ${ }^{52}$.

Om eftermiddagen den 26. rejste dr. Marcus fra Haderslev til Åbenrå for at bringe hustru og børn i sikkerhed. Fra Åbenrå fortsatte han til Rendsborg ${ }^{53}$. Han har utvivlsomt medbragt det overmåde oplysende brev, som borgmester Schow samme dag skrev til hertug Christian August af Augustenborg ${ }^{54}$, med hvem han havde korresponderet i mange år. Brevet bærer tydeligt præy af det indtryk, udfaldet af styrkeprøven i Haderslev har gjort. Laurids Skau organiserer friskarer mod slesvigholstenerne, hedder det: »en behagelig udsigt for os i Åbenrå . Af frygt 


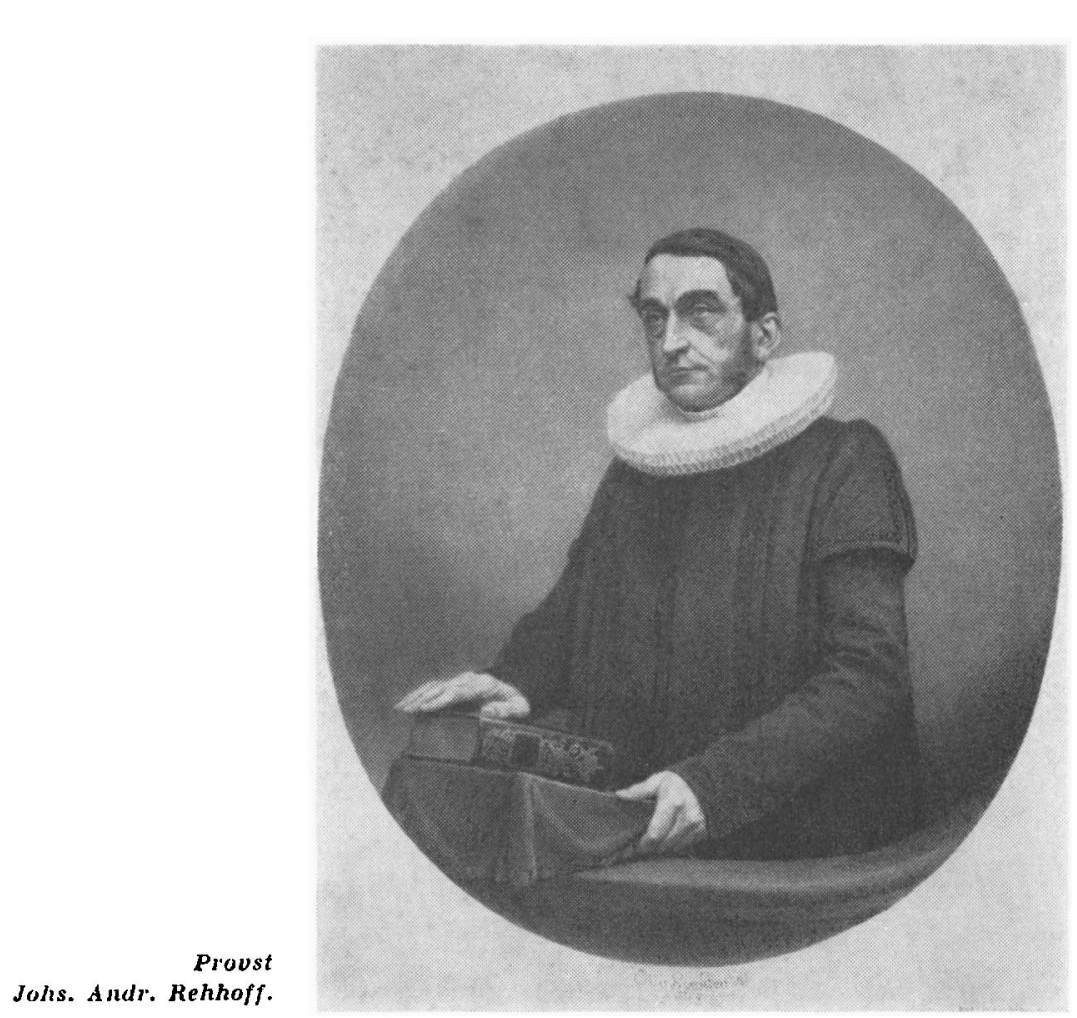

for bønderne har Haderslevs borgere erklaret sig mod den provisoriske regering, 》og nu er Åbenrå målet «. Schow beder derfor hertugen om at opbyde hele sin indflydelse for at sørge for, at der bliver sendt militær til Åbenrå, thi »sådan som det går nu, kan det ikke blive ved med at gả godt «. Man må tage i betragtning, »at vi skal kæmpe mod fanatikere og står som ledere af en $i$ det store og hele indifferent masse «. De fleste embedsmænd tør ikke beslutte sig. »Stemann har jeg med stort hesvær fået til at tage den beslutning, at han vil tilslutte sig den provisoriske regering, og han vil sandsynligvis $i$ morgen eller $i$ overmorgen indsende sin erklæring til regeringen «.

Da Schow havde overbevist Stemann oun nødvendigheden af at anerkende den provisoriske regering, indkaldtes amtets sogne- 
fogeder og befuldmægtigede til et møde på amtshuset den f $\phi l-$ gende dag (27. marts) ${ }^{55}$. Foruden disse og amtmand v. Stemann deltog også provst Rehhoff, herredsfoged Wardenburg, amtsforv. Krogh, husfoged v. Liweh og antsfuldm. Brinckmann i mødet. Om morgenen, $\mathbf{f} \phi \mathbf{r}$ mødets begyndelse, modtog amtmanden den officielle meddelelse om den provisoriske regerings dannelse. Af de mange deltageres udtalelser om mødet fremgår det tydeligt, at det kun var modstræbende, v. Stemann adlød den provisoriske regering. Efter at have opliest denne regerings proklamation udtalte han, at det ikke var hans hensigt at opfordre nogen til at slutte sig til den provisoriske regering eller anerkende de i proklamationen opstillede principper, og at kun fremtiden og en n $\varnothing$ jere unders $\emptyset$ gelse kunne vise, om de var grundede på ret, men at han anså det for sin pligt at opretholde ro og orden. Han tilføjede, at det måtte antages, at kongens vilje ikke var fri. Stemann, fortæller sognefoged Rohde fra Brunde, kunne under sin tale ikke tilbageholde tårer, »jeg antager af kærlighed og hengivenhed for kongen ${ }^{56}$. Rehhoff derimod har tydelig nok søgt at få sognefogederne til at gå videre end til denne upolitiske afg $\emptyset$ relse. Han opfordrede $i$ hvert fald » særskilt « sognefoged Reuter fra Løjt til under de nuværende omstændigheder at vise sig som en mand $^{5 z}$. Forsamlingen var enig om at afvise oprettelse af sikkerhedsvaster på landet samt udbredelse af den provisoriske regerings proklamation ${ }^{58}$.

Byen gæstedes samme dag af den provisoriske regerings overordentlige kommissær, herredsfoged Jacobsen, der skulle reorganisere og inspicere forvaltningen $i$ Åbenrå ${ }^{50}$. Det var sandsynligvis ham, der medbragte anerkendelsesopfordringen til Stemann, og da han havde fuldmagt til at suspendere alle embedsmænd, der ikke tilsluttede sig den provisoriske regering, skyldes det nok ham, at Stemann allerede på denne dag indsendte sin anerkendelse. Det står sikkert også i forbindelse med hans ophold $i$ byen, at Rehhoff denne dag afgav en tilsvarende erklæring ${ }^{6 "}$, at amtsforvalter Krogh meddelte den provisoriske regering st $\varnothing$ rrelsen af sin kassebeholdning ${ }^{61}, \mathrm{og}$ at postmester Moltkes hus pludselig blev besat af tre mand fra sikkerhedskorpset, medens to magistratsmedlemmer bad ham afgive en erklæring $i$ 
Kaptajnlpjtnant Magnus Suenson.

anledning af rygter om, at han ville flygte. (Man har åbenbart frygtet, at han ville medtage kassebeholdningen) ${ }^{a 2}$.

\section{MILIT ERE FORBEREDELSER}

I de følgende dage er Åbenrås historie præget dels af de to stridende parters militære aktivitet, dels af, at danskheden uventet træder frem som en med byens tyskorienterede parti fuldt jævnbyrdig styrke. Danskhedens kærne viste sig at være et hidtil ganske overset befolkningselement, nemlig skibstømrerne ved byens værfter, der var i besiddelse af den uafhængighedsf $\varnothing$ lelse, som småborgerskabet $\mathbf{i}$ så $h \emptyset j$ grad manglede.

Den 25. marts havde den provisoriske regering besluttet at sende tropper ind i Slesvig så langt nord på som muligt ${ }^{03}$, og da herredsfoged Jacobsen den 27. var i Åbenrå meddelte han da også, at man $i$ de nærmeste dage kunne vente et troppekorps $i$ byen $^{64}$. Den 26. marts afmarcherede major Michelsen med 2. 
slesvigholstenske jægerkorps og frikorpsene fra Kiel fra egnen nord for Rendsborg til Flensborgs5. Den 27. marts om aftenen ankom tropperne til Flensborg6 ${ }^{66}$. Her blev de imidlertid stående. Da dr. Marcus den 27. marts bad den provisoriske regering om militær hjælp, fik han som svar, at »der Norden « foreløbig måtte sk $\phi$ tte sig selv, og at det i det hele taget måtte overlades til de enkelte distrikter, om de ville vende sig mod nord eller syd ${ }^{67}$. Det $t \phi r$ antages, at den t $\varnothing$ vende slesvigholstenske besættelse af Åbenrå står i forbindelse med den provisoriske regerings overvejelse af en eventuel afståclse af Nordslesvig til Danmark.

Rygter om slesvigholstenske troppers march fra Flensborg mod Åbenrå nåede det nørrejydske korps' hovedkvarter i Kolding kort efter kl. 16 den 28. marts. Kl. 19 rapporterede general Høegh Guldberg herfra, at det var »upåtvivleligt, at insurgenterne trænger frem og allerede er i Apenrade « ${ }^{68}$. Man besluttede derfor omgående at rykke frem til Haderslev. Den 29. 3. kl. 2,30 nat afmarcherede de f $\varnothing$ rste danske tropper mod syd, og ved middagstid blev Haderslev besat ${ }^{\theta 9}$.

Imidlertid var korvetten "Najaden « under kaptajnlфjtnant Dirckinck-Holmfeldt 26. 3. af gået fra København til Sønderborø̣. 27. 3. fulgte briggen »St. Thomas« under kaptajnl $\phi j$ tnant $M$. Suenson efter med ordre til at underlagge sig kommando af »Najaden «s chef ${ }^{70}$. Den 28. marts kl. 9,30 om formiddagen ankom »Najaden« til Sønderborg, medens »St. Thomas« lagde sig til ankers ved Hardesh $\phi$ j. Dirckinck-Holmfeldt beklagede sig allerede i sin f $\phi$ rste rapport til marineministeriet (28. 3.) over myndighederne i Åbenrå: „Der kom mange indrollerede [dvs. søværnepligtige 7 til mig og beklagede sig over, at de i Apenrade var blevet standset af (jeg tror) herredsfoged Schou\&. Suenson fik fra en forbisejlende skipper en række andre oplysninger om situationen i Åbenrå og foreslog den 29. marts Dirckinck-Holmfeldt, at en dansk orlogsmand skulle afgå til Ábenrå for om muligt at »bidrage til at gyde mod i de dansksindede «. DirckinckHolmfeldt mente imidlertid, at en sådan demonstration ikke ville udrette synderligt, f $\phi r$ de danske tropper rykkede frem.

Det danske militærs planer med hensyn til Åbenrå udtrykkes klarest i den instruktion, som Tseherning 28. 3. udstedte for det 
venstre flankekorps, der skulle operere fra Als og Sundeved: "Når forbindelsen med hovedkorpset [der skulle rykke frem fra Kolding] er tilvejebragt, så at dette samtidig og i forening med venstre flankekorps og en brig, som averteres herom fra venstre flankekorps, kan indeslutte Åbenrå, udf $\not$ res dette hurtigst muligt. Briggen viser ved kugleskud, at den har byen i sin magt, men må dog ikke molestere byen uden i yderste nød. Oprørske embedsmænd og tyske agitatorer forvares om bord. Når Abenrås befolkning er gjort uskadelig «, hedder det endelig, fortsæettes operationerne mod T $\varnothing$ nder $^{71}$

Den 28. marts, da fremrykningen til Haderslev var besluttet, begyndte man at $f \varnothing$ re denne plan ud i livet. Kl. 21 sendte Læss $\emptyset$, som stabschef for det nørrejydske korps, fra Kolding en skrivelse til flotillen ved Als. Heri udtaltes $\emptyset n s k e$ om, at fremrykningen sydpå »måtte blive underst $\varnothing$ ttet fra flotillens side derved, at et eller flere skibe går op ad Apenrade fjord imod byen «. Korpset »skal søge at komme i forbindelse med flotillen og $\varnothing$ nsker, at denne bestraber sig for det samme. Hensigten med denne demonstration formener korpset at måtte være at true byen Apenrade, uden at byen dog beskydes, når dertil ikke er særlig anledning «. Den 30. marts kl. 1,45 nat kom skrivelsen kaptajnløjtnant Suenson i hænde, og kl. 6,30 styrede »St. Thomas« fra Hardeshøj mod Åbenrå fjord.

\section{SKIBSTØMRERNES DANSKE MODAKTIONER}

28. $3-30.3$.

I Åbenrås tysksindede kredse havde nyheden om slesvigholstenske troppers ankomst til Flensborg selvf $\not$ lgelig forbedret humøret, der var dalet stærkt siden Haderslevs ikke-anerkendelse af den provisoriske regering. Hovedkilden til vort kendskab til udviklingen i Åbenrå i de følgende dage er de ovenfor omtalte dagbogsoptegnelser, som C. Gamborg i 1891 »muligst uforandret * offentliggjorde i bladet »Vort Forsvar «. Gamborg, en præstes $\varnothing n$ fra Sjælland, var 1846 blevet ansat hos tømmermester Paulsen og hestyrede 1848 hans varft som mestersvend. Han var da 25 år gammel. »I forventning on troppernes nære ankomst«, skrev han den 28. i sin daghog, »begynder de tysksindede idag at håne 


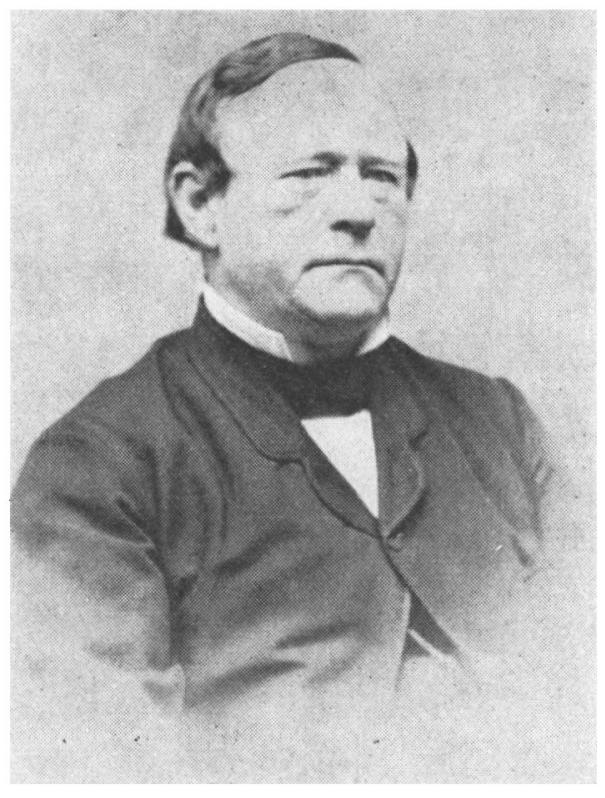

Skibsbygmester

Jïrgen Paulsen.

og chikanere adskillige dansksindede«. Gamborg var der dog ingen, der generede, da han bag sig havde skibstømrerne, »der uden undtagelse er dansksindede . Paulsen (Gamborgs principal) havde i de sidste dage flere gange udtalt, at han håbede at komme til at bygge en afdeling til den kommende tyske flåde, og ved middagstid hejste han igen sit tyske flag. Dette blev signalet til åben modstand fra skibst $\not$ mrernes side. Gamborg fortæeller: »Da jeg efter middag kom ud på pladsen, spurgte jeg t $\not$ mmmermandene, om de var enige med mig $i$, at vi ikke længere ville arbejde under dette oprorsflag. De svarede alle ja, og flere af de yngre begyndte at kaste med sten efter fanen. Dette bad jeg dem dog om at lade være, da jeg nok skulle sø̣rge for, at den kom bort. Jeg gik da ind til hr. Paulsen, som jeg traf ved middagsbordet, og erklarede ham i mit og alle tø̆mmermændenes navn, at vi ville nedlagge arbejdet på hans vaerft, hvis den oprobrsfane imod vor danske konge, som vajede på hans planbygning, ikke blev strøget, og - han adlød!« 
Samme dag udsendte Hans Kopperholdt det første og eneste nummer af et ugeblad: $\gg$ Bulletin «. Det var karakteristisk for den udvikling, der havde fundet sted $i$ de sidste ti år, at bladet udkom på dansk. Det betonede, at Tysklands hjælp til slesvigholstenerne var naer og aftrykte den preussiske konges brev af 24. marts, hvori han lovede stotte til opfyldelse af de slesvigholstenske kravi?. Ved sin åbent protyske tendens virkede bladet imidlertid mod sin hensigt skrammende på vaklende elementer: for sognefoged Borg blev den provisoriske regering »f $\emptyset$ rst helt mistankelig«, da han den 29. så bladet i Åbenrå ${ }^{\text {sa }}$.

Heller ikke den 29, marts kom der slesvigholstensk militar til Shenrå. Borgmester Schow sendte et nyt brev til hertugen, hvori han beklagede sig over, at der stadig ikke var kommet hjælp. Haderslev, skrev han, ville sikkert blive besat om aftenen, og naste dag ville det blive Åbenrås tur ${ }^{74}$. I håb om troppernes ankomst blev der hejst et roksende antal tyske flag i byen. Gamborg talte $i$ formiddagens løb med tømrerne om, shvilken skam det var, at vi danske vedbliver at tåle dette uvasen«. Tømrerne lovede ham, at de om aftenen ville være ham behjalpelige med at skaffe alle de tyske flag af vejen. Der blev nu etableret kontakt med arbejderne ved de to andre varfter, og inden en halv time fik Gamborg besked om, at alle ville vare med $i$ aktionen. Da Gamborg lod Paulsen forstå, hvad der var i gære, ilede denne op i byen, og da Gamborg kl. 2 så Paulsen igen, fortalte denne, at han havde bevaget sine meningsfæller til at tage flagene ned. Fra et barkskib, der var under bygning, så Gamborg nu »den ene fane oppe i byen forsvinde efter den anden. Inden en time var forløbet, så man ikke et oprørsk flag i hele Ảbenrå « Om aftenen var der røre i gaderne. Overalt så man grupper af skibstømrere. En stor skare samledes foran rådhuset. Sikkerhedskorpsets chef, Hans Bruhn, kom ned ad rådhustrappen og søgte at få mængden til at skilles, men måtte hovedkulds retirere op ad trappen. Først da agent Bruhn, om hvem man sagde, at han havde vagret sig ved at anerkende den provisoriske regering, tiltalte tømmermandene, skiltes disse ad, »idet de gav et dundrende hurra for de danske«. 




Skibsreder, agent

Jorgen Rruhn.

Da nogle af tø̆mmerfolkene kl. j den næste morgen (torsdag den 30. narts) kom ind fra L $\phi j$ t, fortalte de, at danske krigsskibe var under opsejling i Genner Fjord. Fra den tidlige morgen hørtes kanonskud uden for fjorden, og kl. 8 blev to krigsskibe iagttaget ved indløbet til den. \$Tiden synes mig nu kommet til at få fanetoget i gang«, skrev Gamborg, som dagen i forvejen havde foreslået, at alle skibstømrere skulle gå i optog gennem byens gader med dannebrog i spidsen. Kl. 9 gik skibst $\varnothing m r e r n e$ fra Paulsens varft i samlet trop ned til havnen, hvor deres kammerater fra de andre verfter sluttede sig til dem. »KI. halv ti var det imponerende tog med et stort dannebrogsflag i spidsen samlet på skibsbroen og satte sig under afsyngelsen af danske fædrelandssange, mange af tø̆mmermændene med øksen på skulderen, i bevagelse op gennem brogaden. Toget gik igennem alle byens hovedgader og vakte overalt stort røre». Gamborg stod ved rådhuset og så optoget drage forbi: »Det var et kosteligt syn her at se resterne af den tapre borgergarde opmarcherede, blege som 
lig, med deres franske rifler over skulderen. De fleste medlemmer har sagt sig los fra korpset på grund af situationens alvor «.

DANSKE KRIGSSKIBE PÅ REIEN; SLESVIGHOLSTENSKE TROPPER I BYEN. OMVELTNINGSPARTIETS NEDERLAG

30. 3.-31. 3.

Situationens alvor bevirkede også, at bykollegierne samledes på rådhuset til drøftelse af den holdning, man skulle indtagc over for kongens krigsmagt, der nu truede både dem og byen med gengaldelse for deres frafald. Det radikale lossrivelsesparti, der $\mathrm{i}$ den sidste uge havde domineret byen, led nu et fuldstændigt nederlag over for byens konservative borgerskab, der stillede sig på det standpunkt, at bykollegiernes ancrkendelse af den provisoriske regering først og fremmest var fremkaldt af deres ynsker om »ikke at give slip på ordenens tøjjler «, og at den ikke måtte opfattes som frafald fra deres konge ${ }^{i 3}$. Man kunne have tankt sig, at borgmester Schow havde varet solidarisk med de

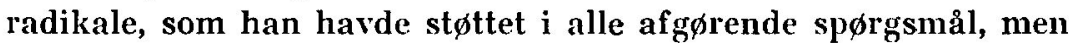
hans tilbøjelighed til at skjule de sande motiver til sine handlinger bag juridisk formalisme gjorde det let for ham nu at forene sig med det konservative flertal.

Ude på fjorden kom »St. Thomas i det stille vejr langsomt nærmere. Med mellemrum affyrede den lose skud. Mange borgere begyndte af frygt for et bombardement at flytte deres ejendele ud af byen, mens skibstømrere og byens unge søfolk samlede sig ved havnen med deres dannebrogsflag, svingede med hatten og råbte hurra ${ }^{76}$. I byen vajede dannebrog forskellige steder ${ }^{77}$. Kl. 2 lod briggen ankeret falde og løsnede en kanon, »hvis brag $\mathrm{i}$ det stille vejr kastes tordnende tilbage fra de omliggende skove og kyster ${ }^{78}$. Magistraten skred nu til udf $\varnothing$ relse af kapitulationen. Agent Bruhns s $\varnothing$ n, kaptajn Hans Bruhn, fik besked om at $f \phi r e$ Suenson til rådhuset, hvis han kom i land ${ }^{79}$. På brohovedet hejstes dannebrog på havnens flagstangso. Her samledes magistraten ${ }^{81}$ og sikkerhedsvagtens chef, skibsreder Hans Bruhn, for at byde krigsskibet velkommen. 
Imens var Gamborg $i$ en jolle, roet af to tømrere, taget ud til »St. Thomas\&, hvor Suenson udspurgte ham om forholdene $i$ byen. Schows virksomhed vidste Suenson allerede besked med, og da han hørte, at de to brødre Karberg endnu var i Åbenrå, bad han Gamborg sbringe dem ligesom borgmester Schow hans hilsen, at det ville glæde ham særdeles at se de herrer ombord hos sig«. Da Gamborg igen var kommet i land, trådte han hen til Schow, »der så ud, som om han skulle synke rent sammen; jeg bragte ham kaptajn Suensons hilsen.

»Hvad skal jeg gøre?» spurgte han, henvendt til agent Bruhn. »Naturligvis gå om bord «, svarede denne.

»Vil De ledsage mig?

गJar.

De steg sammen ned i en båd og lod sig ro ombord.

I båden befandt sig også sikkerhedskorpsets chef, Hans Bruhn, der pillede det hvide bånd af armen undervejs ud til briggens:. Samtalen med Suenson indledtes i f $\varnothing$ lge Schows egen erklæring 15. 4. med »nogle ord om tidsforholdene«, dvs. Suenson bad Schow forklare sin fremfærd over for de indkaldte reserver, og fik som svar, at Schow havde handlet $\gg$ f folge den slesvigholstenske regerings bestemmelse, som var ham kommuniceret $i$ et brev fra prinsen af Augustenborg «. Suenson anså det derfor for rigtigst at beholde Schow om bord ${ }^{\text {ss }}$. Suenson forlangte dernæst, at magistraten skulle sende en depeche pr. stafet til den danske styrke i Haderslev for ham, »Vi var straks rede hertil\&, skriver Schow, og da Suenson krævede, at Schow skulle blive ombord, til der var indløbet svar, var man også indforstået med dette. Klokken halv fire var depechen parat ${ }^{84}$ og blev sendt $i$ land sammen med de to brødre Bruhn. Schow fik anvist plads $i$ chefens kahyt. Briggens besætning gjorde sig nu rede til at gå i land ${ }^{85}$, da topgasterne varskoede, at der syd fra drog tropper mod byen. Det var det 2. slesvigholstenske jægerkorps og 40 dragoner (alle i deres gamle danske uniformer og stadig kommanderet på dansk) under ledelse af major Michelsen, der sammen med et friskarekorps fra Flensborg foretog en rekognoscering $\bmod$ Abenrå. Klokken var da henimod 5.

Disse troppers indmarch forandrede med ét slag - om end 
kun for en kort tid - hele situationen. Brødrene Karberg undgik deres skæbne. Undervejs ned til skibsbroen hørte de om de fremrykkende slesvigholstenere, vendte om og gik dem i møde sammen med meningsfaller fra byen. Gamborg havde forinden, med Paulsens billigelse, nået at få hejst dannebrog på tø̆mmergården.

Flere af de slesvigholstenske frikorpsfolk har i deres erindringer skildret deres dramatiske indtog i Abenrå og deres førsto møde med den danske krigsmagt ${ }^{87}$. Gamborg stod sammen med andre i tømmergården og så briggens mandskab stå fæerdigt ved kanonerne, men uden at forulempe jægerne, der uanfægtede drog ind til byen ${ }^{88}$. Vore herrer friskarefolk $\varangle$, som Heise skriver, havde for en stor del lejet sig vogne til transporten. Ved Posekær teglværk gjorde de holdt og sendte forsøgsvis en vogn med en sort-rød-gylden fane hen ad chausseen. Denne udfordring blev straks besvaret fra $\gg$ St. Thomas «: $\gg$ Da den tyske fane blev observeret at vaje sk $\phi d 2$ skarpe skud imod samme«, rapporterede Suenson. Det var de fø̆rste skud, der på dansk side blev affyret mod fjendtlige tropper under treårskrigen.

Skuddene fik friskarefolkene og dragonerne til skyndsomst at s $\phi$ re omkring. Ad en omvej gennem skovene nåede de senere nordfra ind $\mathrm{i}$ byen. Oven på dagens mange forskrækkelser blev de slesvigholstenske soldater modtaget med særlig jubel af Åbenrås tysksindede indbyggere. Foran rådhuset blev der fra begge sider holdt taler ${ }^{89}$. Der blev kastet kranse ned på dem, man løb omkring med dem arm i arm, og de blev beværtet på bedste måde ${ }^{00}$. If $\phi$ lge Fischer indg $\phi d$ mange af friskarefolkene med deres »skumle og vilde udseende« byens indbyggere en panisk skræk. På grund af orlogsskibets tilstedeværelse og den danske hærs nirhed blev soldaterne ikke indkvarteret hos borgerne; de indlogeredes på slottet eller bivuakerede $\mathbf{i}$ gaderne.

Mens man oppe $i$ byens hovedgader festede for de slesvigholstenske soldater, tog Gamborg i selskab med endnu et par danske ud til »St. Thomas«, der havde lagt sig til ankers ved Laksmølle ved fjordens sydside ${ }^{01}$. Senere på aftenen var Gamborg og Th. Andersens mestersvend Printz på ny ude på briggen med militære oplysninger om de slesvigholstenske styrker. Klokken ni 
så de her borgmester Schow afgå til den højestkommanderende i S $\phi$ nderborg om bord i korvetten »Najaden «s travaille. Klokken halv tolv om aftenen kom et par unge s $\phi$ folk fra byen om bord for at gå $i$ skibets tjeneste som frivillige.

»Tågen lå nu tat og mørk over fjorden, sä at alt var skjult derunder. Vi beh $\phi$ vede kun brugen af vore $\phi r e r$ til vejledning, idet turnernes sang og skrål tydelig lød os imøde fra byen, hvor disse Tysklands ungdommelige helte fejredes af Ảbenrås tysksindede borgere med sande bacchanalier, og bagved os lød på samme tid kommandoen ombord i briggen, hvor chefen til natten lod alt gøre klart for at kunne afslá en mulig fors $\phi g t$ entring fra landsiden. Vi kom lykkelig ind i den lille havn ved Paulsens tommerplads, som vi til vor gliede fandt ubevogtet«, skriver (iamborg.

Klokkèn tô om natlen sâ de dauske orlogsskibe i Als sund to raketter mod nord; det var det mellem $\gg$ St. Thomas og $\gg$ Najaden « aftalte signal om assistance. Kaptajn Steen Bille om bord på dampskibet »Hekla« (han havde den foreløbige kommando over eskadren ved Slesvigs $\phi$ stkystyz) besluttede selv at komme Suenson til hjalp. Klokken 8 om morgenen den 31. marts forlod »Hekla« S $\varnothing$ nderborg og ankom kl. 11 til Åbenrã.

I Haderslev fik general Hedemann samme morgen (31. 3.) efterretning om den fjendtlige styrke i Åbenrå. For enten at lokke den ud af byen eller skræmme den, sendtes to eskadroner under

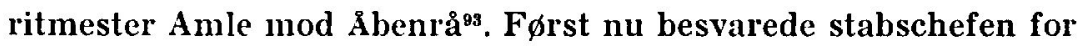
det nørrejydske korps, kaptajn Læss $\varnothing e$, Suensons den 30. 3. afsendte depeche: $\gg$ For udf $\varnothing$ relsen af demonstrationen imod Åbenrâ takkes «, hedder det i svaret; »den har gjort sin gode virkning både hos landfolket, vore venner, og på borgerne i Åbenrå, vore fjender«. Åbenrå ville blive besat den 1. eller 2. april, tilføjedes $\operatorname{det}^{\text {B4 }}$.

I Åbenrå var stemningen meget spandt. Ingen arbejdede pâ skibsvarfterne, og sådan har det vel været overalt i byen. Fra skibene i havnen og flagstangen på brohovedet vajede dannebrog, men rundt omkring byen kantonnerede de slesvigholstenske tropper. Inde $\mathrm{i}$ havnen lå det lille dampskib »König Christian VIII«, der ejedes af et åbenråsk aktieselskab. Da den danske 


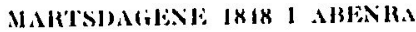

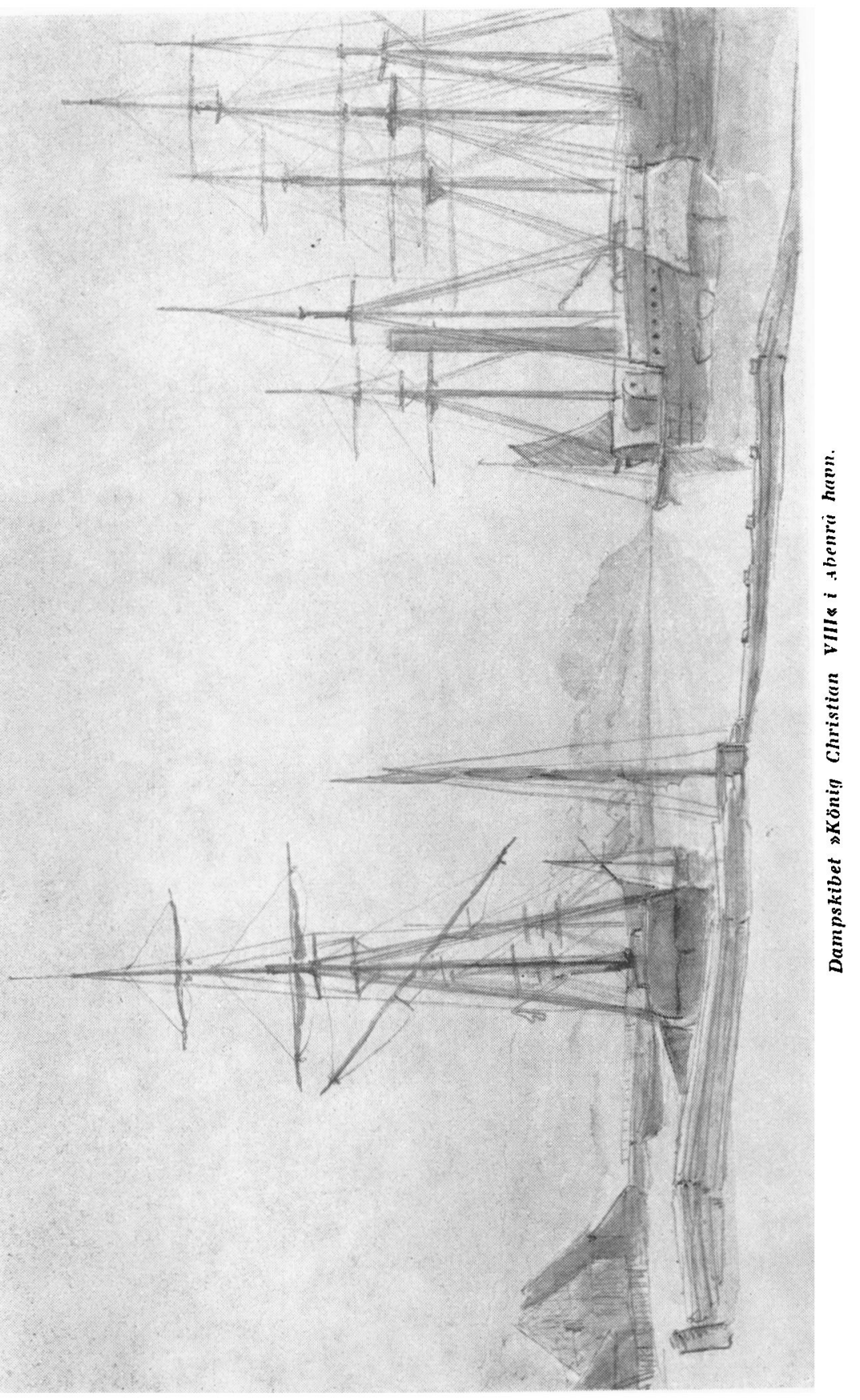


hær i høj grad havde brug for skibe til troppeoverf $\phi$ rsler, besluttede Steen Bille efter konference med Suenson at udtage dampskibet af havnen, - et under de givne omstændigheder sårc dumdristigt forehavende. I.idt over middag lagde »Hekla« sig $i$ et gevarskuds afstand fra havnen med kanonerne indstillet mod byens gader. Under kommando af Suenson roede tre armerede både ind mod land. Så snart de slesvigholstenske tropper havde fået underretning herom, søgte de at barrikadere adgangen til slottet, åbenbart i den antagelse, at der nu ville blive landsat danske tropper. De bler dog hurtigt klar over deres vildfarelse, hvorpå jægerne skyndsomst marcherede ned mod havnen og tog opstilling bagved skibsbygmester Andersens materialehus, ca. 100 skridt fra damperen. Et vabnet sammenst $\phi d$ og alvorlige krigsskader i byen syntes nu uundgåelige, men agent Bruhn, der efter Schows arrestation var byens ledende mand, fik major Michelsen til at love, at han ville trække sig tilbage, hvis danskerne gjorde et landgangsfors $\phi g$; dersom danskerne ikke gik i land, ville han ikke lade affyre et skud, erklærede han. Ledsaget af sin søn Hans gik agent Bruhn nu, »som de eneste af borgerskabet « ud på brohovedet, hvor det »vrimlede af over 100 tøommermænd « ${ }^{\theta 5}$.

Suenson afgav samme dag en rapport, hvori det hed: $\gg$ Efter at være kommet inden for molen kom en jagerofficer med et hvidt lommet $\varnothing$ rklæde om armen ned imod fartøjerne og sagde på dansk, at byen var besat, hvortil jeg svarede ham, at det intet gjorde, da det var Hans Majestæts tjeneste, som blev udf $\phi r t ;$ hertil gensvarede han, at han med våbenmagt måtte sætte sig imod, hvortil jeg observerede, at $i$ så tilfælde ville han til svar på geværild modtage bomber, hvorefter han løb op i byen og kom sencre ned med cirka 2 à 300 mand jægere, som dog holdt dem $i$ tilb $\phi$ rlig afstand og ikke løsnede noget skud. Kl. 1,45 havde dampskibet $\gg$ Christian VIII\& bugsertov fra orlogsdampskibet »Heklak.

Forskellige $\emptyset$ jenvidner: S. W. Rasmussen, Hans Bruhn d.y., og C. Gamborg, har givet malende skildringer af denne spændende episode ${ }^{\text {of }}$. Det fremgår af alle kilder, at tømrerne og søfolkene råbte wurra for de danske marinere, at de var Suenson be- 
hjælpelige med at kaste dampskibet los, og at de på Suensons opfordring søgte at fange den slesvigholstenske officer. I følge generalstabens værk råbte officeren til Suenson: »Det koster blod : «, hvorpå Suenson i bedste stil svarede: „Lad koste! « Gamborg hørte på Paulsens tømmerplads det samme tilråb fra slesvigholsteneren, men derpå følgende svar, råbt af en af matroserne: »Det $g \phi r$ i hede helvede, det koster en $1 \ldots$. \& Den mest sammenhængende beskrivelse giver $\mathrm{S}$. W. Rasmussen, der selv førte pligtåren $i$ en af bådene: » Skyd ham «, råbte Suenson (om jægerofficeren), og en gammel konstabel (Wilhelm Olsen) smed geværet til kinden, men tyskeren trak sig bag om noget t $\varnothing$ mmerværk og gik hen til sine folk, kielerjægerne; der kommanderede han: »Træd an«. Vi entrede $i$ en gesvindighed damperen og kastede fortøjningerne los. Den tyske prajede atter kaptajnen og råbte: »Jeg lader skyde på Dem, hvis De ikke lader dampskibet ligge og ror væk«. $» \mathrm{Ja}$, prøv De på det, jeg svarer med gloende bomber (en lille overdrivelse), ser De, hvad der ligger? « Og han pegede på $\gg$ Hekla og briggen, — og det var sandelig et temmelig højtideligt syn. Jeg så derhen, hvor han pegede, og lige ind i gabet af $\gg$ Hekla«s 60 pd. Besætningen stod ved kanonerne, og skibet var havnen så nær, at jeg så stykboret, som kanonkommandøren holdt $\mathrm{i}$ hånden. Briggens styrbords batteri $8-18 \mathrm{pd}$., alle med fængrør $i$, jo det var lovende udsigter for publikum $i$ land - men værre for os, thi vi var uden mindste dækning imellem tyskerne og ilden fra vore egne skibe «.

Kort efter, at $\gg$ Christian VIII * var bragt ud af Åbenrå havn (det var ved 2-3 tiden), observerede man fra $\gg$ St. Thomas «, at de tyske tropper trak sig ud af byen. I en rapport fra hovedkvarteret i Haderslev 2. 4. 1848 hedder det: „Ved synet af de første dragoner gik fjenden ud af byen ind i skovene; senere er intet set til ham. - Eskadronerne gik vestenom skovene og rekognoscerede egnen til henimod Kliplev uden at træffe på noget «. Sammen med den slesvigholstenske styrke eller kort efter dens af march flygtede det revolutionære partis ledere fra Åbenrå: de to brødre Karberg, Lüders, Asmus Lorentzen, deputeretkollegiets ordfører, K. D. Detlefsen, advokaterne Bruhn og Nissen, lægerne Neuber og Schow (sidstnævnte en broder til borgmeste- 
ren) samt Kopperholdt ${ }^{97}$. Friskarerne fik fra Åbenrå f $\emptyset$ lgeskab af et par af toldbodens embedsmænd: kontrollør, kaptajn v. Wasmer (han blev såret ved Bov og døde af sine sår på garnisonshospitalet i København) og assistent Lüth (der blev taget til fange ved Bov, men vendte tilbage til Ảbenrå i efteråret under våbenstilstanden) ${ }^{\bullet 8}$.

To timer efter den slesvigholstenske styrkes afmarch viste danske tropper sig uden for byen og forlangte at få en samtale med magistraten. Agent Bruhn begav sig da som ældste rådmand sammen med bysekretær Suadicani uden for byen, hvorfra de $i$ en ventende vogn $k \phi r t e$ en time nordpå. Her spurgte en h $\varnothing$ jere dansk officer dem, om byen havde anerkendt den provisoriske regering. De bejaede dette, men tilf $\varnothing j e d e$, at $»$ byen ikke havde haft til hensigt at svigte sin konge $\ll^{99}$.

Samme dags aften havde Steen Bille et møde med magistraten på rådhuset. Efter de radikale slesvigholsteneres fjernelse viste det sig let at nå til en modus vivendi: Magistraten erklærede på ny sin troskab mod kongen, og Steen Bille udstedte derpå to bekendtg $\varnothing$ relser: $i$ den ene opfordrede han til frivillig tjeneste $i$ flåden, $\mathrm{i}$ den anden opfordrede han indbyggerne til lydighed mod magistraten. Næste dags formiddag (1. april) havde Steen Bille en lignende samtale med amtmand v. Stemann.

\section{IGEN UNDER KONGENS SCEPTER}

$$
\text { 31. 3.-3. } 4 .
$$

Som tegn på, at byen var vendt tilbage under kongens scepter, blev den provisoriske regerings plakater nedrevet på Steen Billes ordre. På skibsbroen blev om aftenen den 31. marts en stor mængde af dens proklamationer og forordninger brændt under Suensons tilsyn ${ }^{100}$. Ved denne lejlighed, siges det $\mathbf{i}$ magistratens indberetning 1 . 5. til den provisoriske regerings befuldmægtigede, holdt Frederik Fischer en tale, $\gg$ hvis tendens ikke beh $\phi$ ver en nærmere antydning«. Magistraten benyttede $i$ фvrigt denne autodafé som påskud til at brænde hele korrespondancen med den provisoriske regering, idet man $\gg i$ overensstemmelse med den af kaptajn Suenson iagttagne fremgangsmåde anså det for 
sin pligt at overgive alt, hvad der havde at gøre med den provisoriske regering, til forglemmelse ${ }^{101}$.

Lørdag den 1. april var alt roligt i Åbenrå, rapporterede Steen Bille samme dag til Marineministeriet. »Det danske flag vajede overalt, og man ventede de danske tropper, man indkørte fourage, som kom vester fra. Stemningen i byen, især blandt menig mand, var meget for den danske sag; borgerne $\phi$ nsker kun fred og rolighed og giver efter for $\varnothing$ jeblikkets magthavere; embedsmændenes opf $\phi$ rsel er meget tvetydig «. F $\phi r$ Steen Bille kl. 13 ombord på »Hekla« forlod Åbenrå, sendte han en forholdsordre til Suenson: »Så længe krigen ikke er udbrudt, går De så lidt som muligt angrebsvis til værks $\ll$, hedder det heri med en sætning, der forklarer meget af begge parters besynderlige krigsførelse omkring Abenrå. I en senere skrivelse fra Bille (samme dag) blev det pålagt Suenson at skaffe så mange søværneplistige og frivillige matroser som muligt. Ud for Åbenrå fjord mødte »Hekla * ved 2-tiden dampskibet »Odin«, der var på vej til Fredericia med borgmester Schow ombord som arrestant.

De danske tropper rykkede heller ikke denne dag ind i Åbenrå, men dragoneskadronerne forstærkedes, og deres nærhed prægede livet i byen. Gamborg hilste på de f $\emptyset$ rste danske soldater, da han efter middag bes $\varnothing$ gte skibsbygmester Paulsen på Farversm $\emptyset$ lle (hvortil denne var flygtet), >idet en korporal, som f $\phi$ rte en patrulje, kom igennem haven, just som jeg kom derud «. Henimod aften gik skibst $\varnothing$ mrerne $i$ sluttet trop med dannebrog i spidsen til de fra Haderslev fremrykkende styrkers kantonnement i Genner. De bevidnede deres glæde over danske troppers ankomst og hengivenhed for konge og fædreland «, rapporterede oberstløjtnant Magius straks efter ${ }^{102}$.

Søndag den 2. april marcherede den danske hærs avantgarde mod syd og rykkede kl. halv et ind i Åbenrå. Fortravet udgjordes af 3. kompagni af 3. jægerkorps under kommando af kaptajn F. Hegermann-Lindencrone. Næste dags morgen skrev han i sin melding om indtoget: Ankommen mod Apenrade kom et tog tømmerfolk bærende det danske flag kompagniet i m $\varnothing$ de og gik foran dette igennem byen syngende fædrelandske sange Frederik Fischer skrev i sit ugeblad: $\$$ Vor by har antaget et helt 
andet præg. Danske flag vajer fra huse og skibe... Ovenpå den fortrykte stemning og den lammende skræk hersker den gladeste og livligste bevægelse iblandt indvånerne«.

Mandag den 3. april måtte Sikkerhedskorpset aflevere sine geværer. Dermed var omvæltningspartiets kortvarige herredømme i Åbenrå likvideret. Da den provisoriske regering i slutningen af april igen udstrakte sit styre til Åbenrå, måtte de radikałle nøjes med rollen som en meget aktiv venstref $l \varnothing j$. Situationen forsk $\varnothing$ d sig heller ikke til deres gunst, da borgmester Schow i september vendte tilbage fra sit fangenskab. I deres iver for at fremme den tyske revolution kom de mere og mere i modsæetning til åbenråernes store flertal og forspildte deres mulighed for at samle de brede lag om sig. Derimod dukkede byens almue, uventet for alle, frem på den nationalpolitiske arena. Dens politiske f $\varnothing$ lelser fandt naive udtryk, men ingen kunne være $i$ tvivl om dens danskhed. På denne faste grund fandt også Åbenrås dansksindede borgerskab et sikkert ståsted. $F \emptyset r$ r 1848 havde danskheden i Åbenrå været en spæd plante, der ikke formåede at gøre sig galdende i skyggen af det dominerende slesvigholstenske bourgeoisi. Efter martsdagene $i 1848$ var danskheden $i$ Åbenrå placeret og af alle anerkendt som tyskhedens jævnbyrdige.

\section{NOTER}

1. I det følgende anvendes bl. a. følgende forkortelser:

RA - Rigsarkivet.

LA - Landsarkivet i Åbenrå.

RK - Regeringskommissionen for Hertugd $\varnothing$ mmet Slesvig af 3. april 1848; dens arkiv findes i RA.

2. Brev, dateret Åbenrå 13. 4. 1848 fra Fischer til stiftamtmand v. Sponneck (RK).

3. Se bl. a. Ap. Ugeblad 6. og 27. 10. 1847.

4. Ap. Ugeblad, 9. og 23. 21848 (tillæg).

5. Se ovennæunte brev fra Fischer.

6. Tyske kancelli C. 4. Kancellipræsidentens sager. I. (RA).

7. Ap. Ugeblad 23. 2. 1848 .

8. Ap. Ugeblad 8. 3. 1848.

9. Lyna 18. 3. 1848 .

10. P. Lauridsen: „Da Sønderjylland vaagnede«, 7. bd., s 135.

11. Ap. Ugeblad 4. 4. 1848.

12. Sammesteds.

13. RKs arkiv, VI (RA).

14. Borgerprotokollen 21. 3. 1848 (LA) og Ap. Ugeblad 22. 3. 1848.

15. Schows erklæring 23. 5. 1848 (RK). 
16. Schows erklæring 15. 4. 1848 (RK).

17. Ap. Ugeblad 4. 4. 1848 .

18. Afskrift af brev fra Kopperholdt til H. Karberg 15. 2. 1850; Slesv. Min. 1. dept. A. Politik II. (RA).

19. Forhør 28. 6. og 23. 5. 1848 (RK).

20. Det er betegnende, at den erklæring, som magistraten den 1. maj 1848 afgav til den provisoriske regering, er holdt $i$ en lige så forbeholden tone som erklæringen til den danske regeringskommission.

21. Kopperholdts ovennævnte brev fra 1850.

22. C. Gamborg: , Ungdomsminder fra 1848 \& i , Vort Forsvar «, 1891, nr. 280-283, 285 og 287.

23. Politibetjent $H$. C. Nielsens udtalelser under forh $\emptyset$ ret den 13 . 4 . og postmester Moltkes svar på RKs spørgsmål 13. 4.

24. Schows erklæring af 15. 4. Karakteristisk nok skubber Schow på dette sted af sin erklæring hele ansvaret for de revolutionære aktioner over på sikkerhedskorpset (, nu gjaldt det blot om at adlyde; det var mængden, st $\varnothing$ ttet til sikkerhedskorpset, der nu

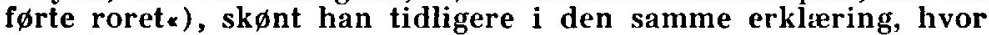
det gjaldt om at forsvare korpsets oprettelse, betonede, at dets medlemmer kom fra det højere og mellemste borgerskab og følgelig var gode samfundsst $\emptyset$ tter.

25. Landesverwaltung. I. Krieg und Politica. Betr. die Rückkehr der Schleswiger... 1851. Norm. Amnestie. (RA).

26. Åbenrå byarkiv. VI, nr. 30. Advokater 1772-1853: Bahnsens notitser juli 1852 (LA).

27. Gamborg, anf. sted.

28. Schows erklæring 15. 4.

29. Ap. Ugeblad 4. 4.

30. Gamborg.

31. Schow 15. 4.

32. Skibsbygger Jürgen Paulsen.

33. Moltkes svar 13. 4. på RKs spørgsmål.

34. Forh $\phi r$ over Schow 23. og 31.5. og over Marcus 23.5. 18.4 (RK).

35. - Tønder By gennem Tiderne , 1943/44, s. 227.

36. Bilag til skrivelse 12. 9. 1848 fra $R K$ til det slesv-holst. kancelli (RK).

37. Afskrift af erklæring fra bykollegierne i Tønder 3. 4.1848 som bilag til borgmester Knudsens svar 15. 4. 1848 på RKs spørgsmål. - Den nøje kontakt mellem slesvigholstenerne i Åbenrå oğ Tønder fremgår også af et af Todsen fremsat forslag til en daglig stafetforbindelse mellem de to byer: ,Freilich dürften die Apenrader weniger Neuigkeiten von hier aus, als wir von dorten erwarten $\%$.

38. Hjelholt: „Flensborgs 'anerkendelse' af den provisoriske regering*, Hist. Tidsskr., 11. rk., 3. bd., s. 387.

39. Forhør over borgmester Langreuter (RK).

40. Gamborg.

41. 21. marts var der fra København givet ordre til at indkalde reservisterne. Ordren må have nået åbenrả den 23., men efter gammel vane afventede amtshuset de detaillerede indkaldelsesordrer fra Fredericia. Disse indtraf den 24. marts, og samme dag udgik indkaldelserne fra amtshuset. Bilag til sagen mod Stemann (RK). 
42. Brev, dat. 26. 3., fra Schow til hertug Christian August (Primkenau-arkivet i Schl.-H. Landesbibl. i Kiel).

43. If $\varnothing$ lge Schow, hvis oplysninger herom ikke bestrides fra anden side, blev der $i$ alt anholdt $30-40$ soldater.

44. Rådsbetjent Ipland 13. 4. (RK).

45. Krigsministeriet. Direkt. for arm. pers. Indkomne sager. Protokol nr. IV, 1848. (RA).

46. Sammesteds.

47. Sammesteds (afskrift).

48. Forhøret i sagen mod Schow 13. 4. (RK).

49. Forh $\phi r$ over Stemann 13. 4. (RA).

50. Skrivelse 5. 4. fra avantgarden $i$ Åbenrå til det nørrejydskc armékorps (RK).

51. Sammesteds.

52. Se f. eks. sognefoged Reuters svar på RKs spørgsmål 15. 4. 1848 (RK).

53. Forh $\emptyset r$ over Marcus 23. 5. (RK).

54. Se ovenfor.

55. Undersøgelsen mod Stemann 13.4.1848. Amtsfuldmagtig Brinckmanns udsagn (RK).

56. Svar på RKs spørgsmål.

57. Reuters svar 15. 4. 1848 på RKs spørgsmål.

58. Sammesteds.

59. Schows erklæring 15. 4.

60. Rehhoffs svar 13. 4. 1848 på RKs spørgsmål.

61. Kroghs svar 13. 4. 1848 på RKs spørgsmål.

62. Moltkes svar 13. 4. 1848 på RKs spørgsmál.

63. Generalstabens værk: ,Den dansk-tydske Krig i Aarene 1848$50 \times, 1867, \mathrm{I}, 1 ;$ s. 86.

64. Schows erklæring 15. 4.

65. Generalstabens værk I, 1; s. 94.

66. Hjelholt: „Flensborgs 'anerkendelse'...*, Hist. Tidsskr. XI, 3; s. 388 .

67. Forhøret over Marcus 23. 5. 1858 (RK).

68. Krigsministeriet. Direkt. f, arm. pers. Indkomne sager. Protokol nr. IV. 1848 (RA). Rapporter, dat. Kolding 28. 3. og 29. 3.

69. Generalstabens værk, $I, 1$; s. $111 \mathrm{f}$.

70. Fremstillingen af krigsskibenes deltagelse i krigsoperationerne hviler her og $\mathrm{i}$ det fø̆lgende på deres skibsjournaler og korrespondanceprotokoller i RA.

71. Generalstabens vark, I, 1; s. 119 .

72. Regenburgs samlinger A III (RA).

73. Borgs svar 15. 4. på RKs spørgsmål.

74. Primkenau-arkivet på Schl.-Holst. Landesbibl., Kiel.

75. Magistratens indberetning til RK 8. 4. 1848: Bilag til sagen mod Schow.

76. sengang jeg drog afsted. Erindringer fra $1848-50 \propto, 1898$ s. 21 (Strandkontrollør S. W. Rasmussens erindringer).

77. Gamborg.

78. Gamborg.

79. Erinnerungen eines Nordschleswigers aus den Kriegsjahren $1848-49$ und 1864 , Åbenrả, 1898. S. 5.

80. Schows erklæring 15. 4. Gamborg.

81. Gamborg omtaler Schow, agent Bruhn og set par slesvigholstenske herrer *. 
82. Dengang jeg drog afsted - - Her siges dette, sikkert fejlagtigt, om Schow.

83. Rapport fra Suenson 31. 3.

84. I depechen hed det, at $\$$ St. Thomas siden kl. 2 lå fortøjet $>$ med

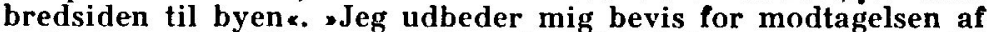
dette brev, der bliver afsendt med stafet. I Apenrade by er det temmelig roligt og intet fjendtligt korps har endnu nærmet sig byen $\alpha$.

85. „Dengang jeg drog afsted -..

86. Generalstabens værk, I, 1; s. 129.

87. Förster Heise's schleswig-holsteinische Feldzugserinnerungen von 1848-1851, mitgeteilt von Felix Schmeissen *. U. å. (1913?). - Die Kieler Studenten zur Zeit der Erhebung 1848, von W. Bahnsen, ehemals Leutnant im 4. schl.-holst. Jäger-Corpse og Fr. v. Wardenburg: "Erinnerungen eines schleswig-holsteinischen Freiwilligen aus dem Frühjahr 1848 i *Erinnerungsblätter an die schleswig-holsteinischen Feldzüge von $1848-51 \ldots$. Altona 1888.

88. Gamborg fortæller, at Suenson ikke ville udelukke den mulighed, at soldaterne ville tilslutte sig den danske sag.

89. W. Bahnsens Erindringer.

90. Ap. Ugeblad 4. 4. 1848. Jfr. W. Bahnsens Erindringer.

91. Nogle bevarede rapporter viser, at man også var i kontakt med landbefolkningen i denne egn og fik oplysninger om, hvem der måtte regnes for farlige slesvigholstenske agitatorer i Åbenrå.

92. Generalstabens værk, I, 1; s. 128.

93. Krigsministeriet. Direkt. f. arm. pers. Indkomne sager. Protokol IV 1848: Rapport fra Hedemann, dat. Hdl. 2. 4. 1848, og rapport fra Wedell-Wedellsborg, dat. Åbenr̊̊ 3. 4.1848 (RA).

94. Marineministeriet. Sekr. og komm.kontoret. Indkomne sager 1848: Bilag til brev fra Steen Bille til statsminister Moltke, dat. Åbenrå 1. 4. (RA).

95. Erinnerungen eines Nordschleswigerse.

96. Generalstabens værk st $\phi t t e r$ sig til en fjerde, mig ukendt kilde.

97. Se bl. a. Ap. Ugeblad 4, 4. 1848 .

98. Slesv. Toldeksp. Ktr. Sager vedr. oprøret 1848-51 A. (RA).

99. Åbenrå magistrats indberetning 8. 4. 1848 til RK, og Åbenrå magistrats indberetning 1. 5. 1848 til den provisoriske regerings overordentlige befuldmægtigede for hertugd $\varnothing m m e t$ Slesvig (koncept i Åbenrås byarkiv II Nr. 4 a - g: Sager vedr. alm. polit. og nat. forhold 1835-67) (LA).

100. Ap. Ugeblad 4. 4. 1848.

101. Indberetning 13.4. om en husunders $\varnothing$ gelse hos borgmester Schow (RK).

102. Nørrejydske Armékorps. Justitsvæsen 1848. Nr.5 (Hærens arkiv). 